
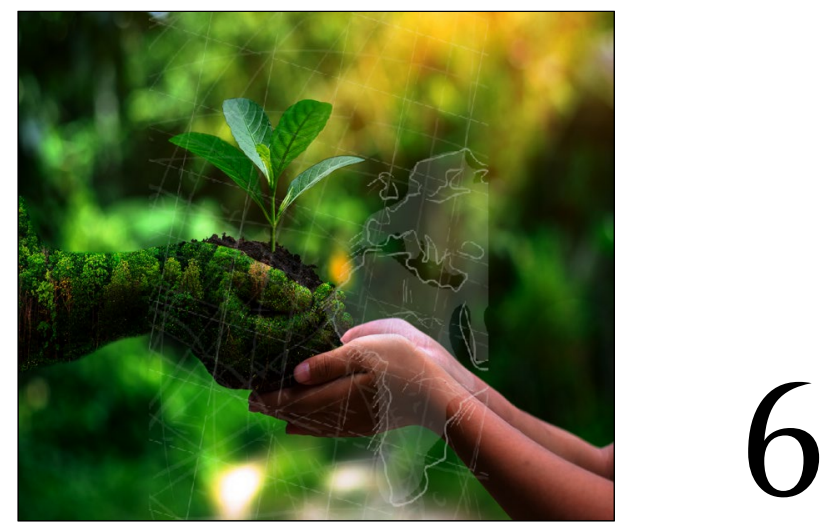

\title{
LIFE-CYCLE MANAGEMENT FOR SUSTAINABLE INFRASTRUCTURE PLANNING AND DEVELOPMENT IN AFRICA
}

Getachew Assefa and Toolseeram Ramjeawon

\section{Introduction}

The mobility of people, goods and services, and information through transport, energy, water and wastewater, and ICT infrastructure are at the heart of global and national socio-economic development. How these people, goods and services, and information are moved from one place to another and how the choice affects economic, social and environmental quality continues to be the subject of inquiry in many fields of research and practice. The type and spread of infrastructure systems in any country play a strategic role in influencing its path to sustainable development.

The global infrastructure spending between 1992 and 2013 was 3.5 percent of world GDP, and Africa spent 3.1 percent of its GDP during that period (McKinsey Global Institute, 2016). The world is expected to invest around 90 trillion USD in infrastructure over the next 15 years and developing countries will need to 
nearly double the annual investment to $\$ 1.9$ trillion $^{1}$ per year between 2016 and 2030 (McKinsey Global Institute, 2016). In addition to its role in society and the economy, long operational lifetimes make infrastructure potentially impactful on the environment and vulnerable to climate variations over the many decades of its use.

According to the United Nations Environment Programme (UNEP), only 25 percent of the infrastructure that will be in place in 2050 exist today (Egler \& Frazao, 2016). This provides numerous opportunities for the development of developing sustainable infrastructure systems with long lifespans. Typical lifespans of infrastructure range from 20 years for roads and petrol stations to 200 for public buildings like town halls (Wright et al., 2018).

Africa needs to ensure that its new infrastructure systems leapfrog the inefficient, sprawling and polluting systems of the past and must strive to develop systems that are sustainable, resource-efficient, low-carbon and climate-resilient. Although sustainable infrastructure could increase upfront capital costs by roughly 5 percent (Egler \& Frazao, 2016), it can have lower operating costs over the life of the investment while reducing risks and negative externalities. Petit-Boix et al. (2017) identified 28 potential improvement strategies for sustainable infrastructure and urban sustainability. Most strategies point to increased process efficiency, the implementation of greener materials/designs and the integration of new technologies into the existing pool of alternatives. Sustainability and resilience must be embedded into standard planning and engineering practice to deliver infrastructure that provides a good service of the right quality, on time and at the lowest cost.

The term 'sustainable infrastructure' is often represented in different ways including interchangeably used with the terms 'green' infrastructure or 'smart' infrastructure. From a life-cycle perspective, we can distinguish the following typical stages of infrastructure planning and delivery: Planning, Development (outline design), Implementation (detailed design and construction), Operation and Decommissioning. In this chapter, sustainable infrastructure is used in the context of the definition used by the Inter-American Development Bank (IDB) as infrastructure that is 'planned, designed, constructed, operated and decommissioned in a manner to ensure economic and financial, social, environmental (including climate resilience) and institutional sustainability over the entire life cycle' (IDB, 2018:11). The definition captures a number of frameworks, principles and standards and encompasses the four major pillars of sustainability, namely economic, social, environmental and institutional.

$1 \quad$ All dollars (\$) are US dollars unless otherwise mentioned. 
Sustainable infrastructure systems enable a community or country to achieve a more sustainable form of economic development adaptable to global changes and the changing needs of societies. They promote inclusiveness, safety and resilience characterised by social, environmental and economic dimensions (Colombo et al., 2017; Global Infrastructure Basel Foundation, 2017; International Finance Corporation, 2017; International Institute for Sustainable Development, 2017). Creating sustainable cities strongly depends on ensuring sustainably developed and operated important infrastructure systems supported by life-cycle insights as noted by Assefa (2019). Within any one of the life-cycle stages, sustainability can be improved by what is done at each stage and particularly by what questions are asked. The biggest opportunities are often in the earlier stages of the process and also at the very start of each stage (Ainger \& Fenner 2014; Braganca, Viera \& Andrade, 2014; Guthrie \& Konaris, 2012). A review of existing evaluation tools shows major gaps in the coverage of sustainability principles at the upstream planning stage, as most focus mainly or entirely on the design stage and stages beyond it.

\section{Sustainable infrastructure for SDGs and Agenda 2063 in Africa}

There is increasingly significant pressure on the infrastructure of African cities due to rapid population growth and urbanisation The population has grown at an annual rate of 2.53 percent from 1950 to 2015 and is predicted to increase from 1.18 billion in 2015 to 2.44 billion in 2050 (United Nations Department of Economic and Social Affairs, 2015). At the same time, the continent is experiencing rapid urbanisation, at a rate of 3.5 percent during the period 2000 to 2015, the highest rate in the world. It is estimated that by 2030, more than 50 percent of the population in Africa will be living in cities, and this percentage is expected to increase even further and reach over 60 percent by 2050 (United Nations Human Settlements Programme [UN-Habitat] \& United Nations Economic Commission for Africa [UNECA], 2015). This means that African towns and cities will host 1.26 billion people (Sow, 2015) - nearly a quarter of the world's urban population, presenting considerable demands on infrastructure systems. Each year, an additional 14 million people join the urban population in Sub-Saharan Africa (UN-Habitat, 2010) with the vast majority (70 percent) living in ' informal settlements' and slums because of insufficient infrastructure and poor institutions.

\section{Current state of infrastructure in Africa}

Africa's infrastructure lags well behind that of other developing countries (see Table 6.1). The African Development Bank (AfDB), whose strategy for 2013-2022 made infrastructure development one of its operational priorities, notes that 'Africa 
still has massive infrastructure needs', yet invests only 4 percent of its gross domestic product (GDP) in infrastructure, compared to China's 14 percent investment (AfDB, 2013).

Table 6.1 Africa's infrastructure compared to other regions, 2013 (Source: Adapted from AfDB, 2018:76)

\begin{tabular}{|l|l|c|c|c|c|}
\hline Sector & Infrastructure & Africa & Asia & $\begin{array}{c}\text { Latin } \\
\text { America }\end{array}$ & Europe \\
\hline \multirow{2}{*}{ Transport } & Paved road density (km per 100 $\mathrm{km}^{2}$ of land area) & 2 & 25 & 3 & 122 \\
\cline { 2 - 6 } & Railway line $(\mathrm{km})$ & 46380 & 197610 & 89002 & 85986 \\
\hline \multirow{2}{*}{ Power } & Electricity production (per capita $\mathrm{kWh})$ & 572 & 1930 & 2116 & 3355 \\
\hline & Electricity access (percent of total population) & 46 & 88 & 97 & 100 \\
\hline Water and & Improved water (percent of total population) & 69 & 90 & 94 & 99 \\
\hline sanitation & Improved sanitation (percent of total population) & 39 & 61 & 82 & 93 \\
\hline \multirow{2}{*}{ ICT } & $\begin{array}{l}\text { Fixed broadband (subscriptions per 100 } \\
\text { population) }\end{array}$ & 1 & 6 & 9 & 15 \\
\hline & Mobile cellular (subscriptions per 100 population) & 73 & 85 & 115 & 119 \\
\hline
\end{tabular}

Africa has 15 percent of the world's population but only 3.2 percent of world electricity-generating capacity. More than half of the world's population without electricity are Africans. According to research from the World Bank Group, 48 countries of sub-Saharan Africa (with a combined population of 800 million) generate roughly the same amount of power as Spain (with a population of 45 million). Per capita, yearly consumption of energy in sub-Saharan Africa (excluding South Africa) is $180 \mathrm{kWh}$, against $13000 \mathrm{kWh}$ in the United States and $6500 \mathrm{kWh}$ in Europe (Dethier, 2015). Energy intensity and $\mathrm{CO}_{2}$ intensity in the continent are also very high, thus giving evidence of unclean and inefficient energy supply chain (Saghir, 2017). It is estimated that only one-third of Africans living in rural areas are within two kilometres of an all-season road, compared with twothirds of the population in other developing regions.

The African Development Bank, based on a set of targets for 2025, estimated Africa's needs of the total investment for infrastructure at $\$ 130$ billion to $\$ 170$ billion per year between 2018 and 2025 (AfDB, 2018) with a financing gap of $\$ 68$ billion to $\$ 108$ billion. Around two-fifths of the investment need is for water and sanitation that faces an ambitious target of 100 percent access in both urban and rural Africa.

Africa also faces higher access costs for all infrastructure services compared with other developing countries. For instance, freight costs in sub-Saharan Africa per ton-kilometre are $\$ 0.04-\$ 0.14$ compared to $\$ 0.01-\$ 0.04$ in other developing regions, leaving African markets less competitive on the international level. 
The situation worsens for the 16 landlocked countries in the continent where trading costs are much higher than in African coastal countries (Foster \& BriceñoGarmendia, 2010). According to the World Economic Forum's Global Competitive Index for 2014-15, more than half of the 20 least competitive countries in the world are found in sub-Saharan Africa, due, in large part, to the region's deep infrastructure deficit. A World Bank study found that the deficit reduced national economic growth by two percentage points every year and cut business productivity by as much as 40 percent, making Africa - in spite of its enormous mineral and other natural resources - the region with the lowest productivity levels in the world (Foster \& Briceño-Garmendia, 2010).

Among factors explaining the low infrastructure provision in Africa according to AfDB (2018) is a weakness in infrastructure planning. The continent has more countries with low population densities than other developing regions with an average population density of 70 people per $\mathrm{km}^{2}$. This is lower than that of other low and lower-middle-income countries in the world with 125 and 91 people per $\mathrm{km}^{2}$ respectively.

The recognition that Africa's infrastructure gap is enormous and poses a severe threat to development has led to infrastructure programmes at the national and regional levels, such as the Programme for Infrastructure Development in Africa (PIDA) that promotes regional corridors to create conditions for higher economic density and enhanced regional markets. PIDA envisages the development of highways, railways, hydroelectric power generation capacity and interconnected power lines, throughput capacity at the ports over the years leading to 2040 (PIDA, 2011).

\section{Key to success of the UN Sustainable Development Goals and Agenda 2063}

There are global and continental goals and commitments that are expected to shape the infrastructure development in Africa, such as the UN Sustainable Development Goals (SDGs) of 2015, the African Union's Agenda 2063 of 2003, the and African Development Bank's High Five Goals of 2012. The SDGs are a global set of 17 goals for all countries of the world to pursue by 2030 based on the recognition that all countries are developing countries when it comes to sustainable development. Infrastructure is directly included in SDG 9: 'Build resilient infrastructure, promote inclusive and sustainable industrialisation and foster innovation'. Egler and Jurik (2017), citing OECD's work on relations between infrastructure development and SDGS, noted that more than 80 percent of the SDGs are related to infrastructure in different ways. 
Agenda 2063, adopted by African countries, has a forty-years long vision of crisscrossing the continent with 'world-class infrastructure' (African Union Commission [AUC], 2015). Africa's common priorities outlined in Agenda 2063 are also fed into the development of Agenda 2030 through the African Common Position on SDGs. There is a strong alignment between SDG 9 and Agenda 2063 as detailed by UNECA (2017). SDG 9 has 8 targets and 12 indicators and is aligned with eight goals of Agenda 2063. SDG 9 is thus one of the most critical goals in support of Africa's aspiration for rapid development and transformation and achieving the other SDGs and Agenda 2063 targets. Achieving the goals should be done in ways that will boost economic development, protect the environment and provide African societies with a variety of social benefits. The continental African Development Bank has also set its High Five Goals (2013-2022) namely, lighting up and powering Africa, feeding Africa, integrating Africa, industrialising Africa, and improving the quality of life for the people of Africa. All five areas are related to infrastructure development in different ways. Unless the infrastructure deficit in the continent is addressed sustainably it will continue to be a significant impediment to the achievement of the SDGs, the Agenda 2063 goals and AfDB's High Five Goals.

\section{Challenges and opportunities for the African infrastructure sector}

The infrastructure landscape in Africa is marred by challenges such as low levels of development, coverage, access, and maintenance of existing systems. The longevity of infrastructure poses a challenge when the infrastructure is developed in a suboptimal way as any problems associated with it will remain in place for decades as part of a broader lock-in effect. Current construction practices are far from allowing for separation of the construction materials at the end of the service life of the structures for reusing and recycling. Infrastructure systems span over large areas of land that could be used for other purposes and the systems affect flora and fauna on surrounding areas. Broader socio-economic challenges related to technology, manufacturing capability and the human resource underpin the sector. Institutional fragmentation, low efficiency and institutional instability should be overcome for better planning outcomes. Undeveloped or underdeveloped infrastructure associated with low access, low connection and poor quality of infrastructure is a challenge for social and economic development.

On the other hand, the low level of infrastructure development provides an opportunity to plan and develop new infrastructure systems sustainably. Abundant labour at a relatively low cost, the availability of land, a young population, fast economic growth, abundant renewable energy and materials resources, the potential for increased intra-Africa trade, and the presence of transnational organisations like regional economic communities, provide opportunities for transforming the 
infrastructure in African countries. If resources are harnessed properly, Africa has the opportunity to do more, to do it right, to create jobs, to influence the type of economic activities to offshoot, to account for infrastructure interdependency, to consider the full life-cycle impact and to adapt to climate change.

Addressing the challenges and capitalising on the opportunities in the infrastructure sector in Africa will be critical in creating an inclusive, low-carbon, climate-resilient and resource-efficient society.

\section{Inclusive society}

Intragenerational and intergenerational equity is the cornerstone of sustainable development. The challenge in many countries, even as they grow economically close to double-digit figures, is the ensuing inequality between low-income and high-income segments of the society. The inclusiveness aspect goes beyond the income gap in capturing how the vulnerable part of society in Africa are treated. These include children, women, youth, old people, people with special needs, the poor, rural communities and pastoralists. Lack of education, health services, decent work, and social security are among the factors that create the social divide. Most, if not all, of these deprivations are associated with connectivity and access to infrastructure systems such as schools, hospitals and health centres, transport, electricity, waste and wastewater services. A robust economic growth pathway that trickles down to people at lower-income levels should be supported by infrastructure systems that decrease the social divide through job opportunities and equitable access to health services and education (Colombo et al., 2017). Infrastructure systems should be planned and developed to support African countries to overcome socio-economic vulnerabilities by seizing opportunities such as the large young population and increasing middle class in the future. Economic conditions and needs of the new generation of Africa in the next four to five decades and beyond demands new infrastructure that creates positive socioeconomic dynamics (Pegram, Seddon-Daines, Reddy, Sulieman \& Baletta, 2017). Filling the quantity and quality gap of infrastructure in rural and urban Africa is a step forward in building an inclusive society. Sufficient and reliable infrastructure enhances business by creating fair conditions replacing what would otherwise be skewed toward the top high-income members of the society (Colombo et al., 2017).

\section{Low-carbon society}

A carbon-constrained world following the fulfilment of the Paris Climate Agreement requires the development of new low-carbon infrastructure systems and redeveloping existing assets with a low-carbon goal (Kennedy \& CorfeeMorlot, 2013). The move to a low-carbon society needs to start by targeting the high-carbon sectors of the economy in each country for redevelopment and new 
development plans, such as personal and goods transport, electricity generation, agriculture, fossil fuel extraction, transport and manufacturing (e.g., cement).

A transition to a fossil fuel-free economy requires shifting to low-carbonintensity fuels first (e.g., natural gas) as African countries transform and leapfrog to an economy powered by renewables. With improved battery technology and innovations in personal and goods transport, Africa needs to develop its transport sector to facilitate renewably-powered electric cars. Embedded infrastructure, such as solar roads where the roads are covered with solar panels to generate electricity to power vehicles, is one innovative way of utilisation land for more than one infrastructure systems. In areas where there is no other productive use of land, large-scale high-efficiency and self-cleaning solar and wind farms can be developed where transmission and distribution to where the demand for electricity is viable.

In urban centres, in addition to solar roofing, which can also be applicable in rural areas, building integrated solar PV systems should be considered where the insolation and orientation allow economic feasibility. Biofuels can play a significant role in the move to a low-carbon society in Africa if it can be done without negatively affecting food availability and prices and compromising other more important uses of the biomass. The cleanest and most economical way to develop in a significantly decarbonised path is, however, to embark on broad and substantial improvements in fuel and energy utilisation efficiency at production, transmission and distribution, and consumption stages in all sectors. Economic, technical and regulatory measures should be in place to incentivise good practices and discourage bad practices of energy consumption. Measures of deep cuts in building energy use including lighting and air conditioning, the fuel consumption of transport vehicles and other types of machinery, and energy consumption in the manufacturing sector will accelerate the journey to a low-carbon economy. A new economy fuelled by solar, wind, hydro, geothermal and other renewable sources of energy can then be built on a high-energy and carbon-efficient foundation.

\section{Climate-resilient society}

The planning and development of infrastructure systems in Africa must consider the operational context beyond two or three decades in the face of new climate future. Temperature increases due to climate change in Africa will be one and half times greater than the global increase (AUC, 2015). Some areas in the continent will get much drier in the coming decades while other parts of Africa will be wetter than before. These changes will affect the technical performance and capacity of infrastructure systems and will be detrimental to social and economic development. They need to be designed beyond mean climate conditions to 'withstand more extreme weather conditions' (Kennedy \& Corfee-Norlot, 2013). The cities of 
Abidjan, Accra, Alexandria, Algiers, Cape Town, Durban, Casablanca, Dakar, Dar es Salaam, Djibouti, Freetown, Lagos, Libreville, Lome, Luanda, Maputo, Mombasa, Port Louis and Tunis will be severely impacted by climate change (AUC, 2015). The urban and regional infrastructure in these cities and small island states need to be developed considering resilience and adaptive capacity. The resilience of the networks of infrastructure will be undermined resulting in underperformance in face of new climate conditions different than what they are planned for (Lempert et al., 2015). Kennedy and Corfee-Norlot (2013) rightly argue for coupling the development of comprehensive strategic infrastructure plans with national climate change goals. These long-lived investments need a built-in mechanism to protect the developed infrastructure systems from the damage that would otherwise incur greater retrofit and replacement cost (Pegram et al., 2017). Adaptive capacity in many countries of the continent should be enhanced given their existing planning systems are far from accounting for changes in configuration and capacities of the infrastructure in response to future climate change projections. Accounting for an adaptation specifically is important in the planning of climate-sensitive infrastructure systems, such as water supply infrastructure, irrigation infrastructure and hydropower infrastructure.

\section{Resource-efficient society}

The economic and non-economic wellbeing of African countries depends to a large extent on biotic and abiotic resources. A massive amount of material resources is entrenched in existing infrastructure stocks and will continue to accumulate unless there is a transformational change on how infrastructure systems are planned and developed. With increased urbanisation, this material consumption is projected to grow significantly. According to a report by the International Resource Panel (IRP), domestic material consumption per capital will be around 8-17 tonnes per year which will exceed the 6-8 tonnes per capita per year required to decouple quality of life from an increase in material consumption. Domestic material consumption in urban areas in Africa will see a growth of 790 percent by 2050 relative to 2010, which is the largest in the world. The percentage growth in Africa is remotely followed by a 220 percent growth in southern Asia while the world average will be at 116 percent (IRP, 2018). A resource-efficient economy needs to identify where most resources are used and wasted: from the huge amount of resource wastage at mining sites to waste generation at processing and manufacturing of materials and products facilities. Depending on the type of product, wastage is also rampant during consumption. A large amount of resource dissipation occurs also during the end-of-life of long-lived technical systems. Sound planning and strategic decision-making around infrastructure systems play a big role in addressing these inefficiencies and advancing a resource-efficient society. Dematerialisation, 
material substitution, and reuse and recycling should be part of the portfolio of solutions in infrastructure planning. Land, another important resource in relation to infrastructure planning, will also see a significant increase in urban Africa, and by 2050 , will reach a size comparable to that in the highly urbanised North American region.

Planners and politicians play a role in articulating their judgements based on technical knowledge and opinions in crafting solutions that mitigate the resource challenges of infrastructure systems. During a sustainable infrastructure planning process, knowledge from different sectors should be used and appropriate tools should be utilised.

\section{Knowledge and tools for sustainable infrastructure}

The evaluation of environmental, social and economic sustainability is one of the major criteria in the assessment of strategic plans for infrastructure (Dominguez, Truffer \& Gujer, 2011). The utilisation of emerging knowledge and tools that underpin the planning and development of sustainable infrastructure is important.

\section{Knowledge on the strategic planning of sustainable infrastructure}

For sustainable infrastructure planning, development and management in Africa, discipline-specific know-how should be supported by knowledge created and deployed through interdisciplinary platforms including technical and nontechnical sources of innovative ways of transforming the planning process. Sound decision-making needs inputs from knowledge surrounding planning and strategic decision-making, institutions, training and capacity building, accounting, and logistics. Knowledge about climate change futures, natural infrastructure networks and deep uncertainties arm planners and decision-makers with tools that transcend conventional approaches. All these are best served through the creation and dissemination of context-specific interdisciplinary and/or transdisciplinary knowledge that can be categorised into areas of system dynamics, nature-based solutions, smart-city solutions, and integrated and distributed infrastructure (Table 6.2). 
Table 6.2 Knowledge basis useful for sustainable infrastructure planning

\begin{tabular}{|c|c|c|c|}
\hline $\begin{array}{l}\text { Knowledge } \\
\text { base }\end{array}$ & Features & $\begin{array}{l}\text { Relevant } \\
\text { infrastructure } \\
\text { elements or aspects }\end{array}$ & Applications \\
\hline $\begin{array}{l}\text { System } \\
\text { dynamics }\end{array}$ & $\begin{array}{l}\text { - Mapping and understanding } \\
\text { systems and interactions } \\
\text { - Modelling and facilitating } \\
\text { analysis, communication and } \\
\text { learning about real-world } \\
\text { problems }\end{array}$ & $\begin{array}{l}\text { - Technical systems, } \\
\text { social systems and } \\
\text { environmental systems } \\
\text { - Flows of materials, } \\
\text { wealth, energy, labour, } \\
\text { waste and information }\end{array}$ & $\begin{array}{l}\text { Expanding boundaries of } \\
\text { mental models, and the time } \\
\text { horizon to see patterns of } \\
\text { behaviour created by the } \\
\text { underlying feedback structure, } \\
\text { beyond most recent events }\end{array}$ \\
\hline $\begin{array}{l}\text { Nature-based } \\
\text { solutions }\end{array}$ & $\begin{array}{l}\text { - Utilising natural systems } \\
\text { like wetlands, forests, or } \\
\text { mangroves that can substitute } \\
\text { conventional man-made } \\
\text { infrastructure }\end{array}$ & $\begin{array}{l}\text { - Dams and water } \\
\text { treatments plants, } \\
\text { wastewater management }\end{array}$ & $\begin{array}{l}\text { Increasing the levels of } \\
\text { sustainability and resilience of } \\
\text { conventional infrastructure } \\
\text { Harnessing their additional } \\
\text { services and non-use services }\end{array}$ \\
\hline $\begin{array}{l}\text { 'Smart-city' } \\
\text { solutions }\end{array}$ & $\begin{array}{l}\text { - Using disruptive technologies } \\
\text { to affect the demand side } \\
\text { and the supply side of } \\
\text { infrastructure } \\
\text { - Data-driven planning and } \\
\text { management of infrastructure } \\
\text { networks and services }\end{array}$ & $\begin{array}{l}\text { - Transport systems, } \\
\text { energy systems, } \\
\text { buildings }\end{array}$ & $\begin{array}{l}\text { Understating the different } \\
\text { elements of urban systems and } \\
\text { their interactions } \\
\text { Supplying information and data } \\
\text { for better performance }\end{array}$ \\
\hline $\begin{array}{l}\text { Integrated } \\
\text { and } \\
\text { distributed } \\
\text { infrastructure }\end{array}$ & $\begin{array}{l}\text { - Planning for infrastructure } \\
\text { system integrated by data, } \\
\text { function and governance } \\
\text { - An integrated system of } \\
\text { man-made and natural } \\
\text { infrastructure } \\
\text { - Finding the right size and } \\
\text { location of infrastructure } \\
\text { networks and striking an } \\
\text { optimal infrastructure mix }\end{array}$ & $\begin{array}{l}\text { - Transport systems, } \\
\text { energy systems, waste } \\
\text { management systems, } \\
\text { wastewater treatment } \\
\text { systems, buildings }\end{array}$ & $\begin{array}{l}\text { Capturing synergy between } \\
\text { infrastructure systems avoiding } \\
\text { sub-optimal solutions } \\
\text { Addressing value conflicts } \\
\text { between different aspects } \\
\text { Supra-sectoral institutional } \\
\text { arrangements for planning } \\
\text { and managing integrated } \\
\text { infrastructure systems }\end{array}$ \\
\hline
\end{tabular}

The knowledge base outlined in Table 6.2 and related concepts and guides contribute to the transformation of African infrastructure planning bodies that need to be supported in embracing discursive strategic planning instead of conventional planning (see Table 6.3). 
Table 6.3 Conventional planning versus discursive planning

\begin{tabular}{|c|c|c|c|c|c|c|}
\hline $\begin{array}{l}\text { Type of } \\
\text { planning }\end{array}$ & Objective & Approach & Changes & $\begin{array}{l}\text { Number of } \\
\text { alternatives }\end{array}$ & Scenario & Adaptability \\
\hline $\begin{array}{l}\text { Conventional } \\
\text { planning }\end{array}$ & $\begin{array}{l}\text { - Optimising } \\
\text { the status } \\
\text { quo } \\
\text { - Withstanding } \\
\text { events of } \\
\text { high intensity } \\
\text { based on a } \\
\text { statistical } \\
\text { analysis of } \\
\text { past trends }\end{array}$ & $\begin{array}{l}\text { - Predict- } \\
\text { and-act; } \\
\text { forecasting } \\
\text { the most } \\
\text { probable } \\
\text { future } \\
\text { - Reactive } \\
\text { planning }\end{array}$ & - Incremental & - Limited & - Future needs & $\begin{array}{l}\text { - Less } \\
\text { adaptable }\end{array}$ \\
\hline $\begin{array}{l}\text { Discursive } \\
\text { planning }\end{array}$ & $\begin{array}{l}\text { - Performing } \\
\text { well across } \\
\text { a wide range } \\
\text { of plausible } \\
\text { future } \\
\text { conditions }\end{array}$ & $\begin{array}{l}\text { - Sustainability } \\
\text { and } \\
\text { robustness } \\
\text { - Exploration } \\
\text { of a wide } \\
\text { range of } \\
\text { future } \\
\text { uncertainties } \\
\text { - Proactive } \\
\text { planning }\end{array}$ & - Transformational & - Broad & $\begin{array}{l}\text { - Objectively- } \\
\text { assessed } \\
\text { needs and } \\
\text { demand } \\
\text { management } \\
\text { strategies } \\
\end{array}$ & $\begin{array}{l}\text { - Adaptable to } \\
\text { rapid changes } \\
\text { in demand } \\
\text { as well as } \\
\text { external } \\
\text { conditions } \\
\text { - Flexibility to } \\
\text { accommodate } \\
\text { changes in the } \\
\text { face of future } \\
\text { uncertainties }\end{array}$ \\
\hline
\end{tabular}

\section{Tools for sustainable infrastructure}

In their work on energy policy, which can be reasonably extended to other infrastructure systems, Colombo et al. (2017) argue that extending the productionbased approach to a life-cycle perspective that includes a consumption/operation phase is important in understanding infrastructural links between sectors and economies. This extension spurs life-cycle management (LCM) that integrates the supply chain with the value chain in making a significant shift from the traditional focus on internal cost savings, compliance and risk management to a broader scope that links sustainability to business values and value creation (Rebitzer, 2015). The core principle of sustainable infrastructure planning and development should be to assess the benefits, impacts and costs and hence viability of an infrastructure plan on a full life-cycle basis. Infrastructure systems as long-lasting assets are one of the most suitable areas for successful utilisation of LCM insights. Life-cycle management is about managing life cycles requiring the cross-organisational collaboration of public and private actors at all life-cycle stages and enabling them to tap into the body of knowledge and resources of each other (Nilsson-Lindén, Baumann, Rosén \& Diedrich, 2014). According to Harbi,Margni, Loerincik and Dettling (2015), LCM offers a 'flexible integrated management framework of concepts, techniques and procedures' on how to operationalise sustainable actions by, for example, helping manage 'expectation of stakeholders' along the life cycle. Inspired by Jensen and Remmen's (2006) definition of product LCM from a planning perspective, LCM is defined here as the application of life-cycle thinking 
to infrastructure planning practice, with the aim to manage the total life cycle of infrastructure systems towards more sustainable development and management.

Depending on the level of application, point of entry and degree of analytical content, an ecosystem of the LCM toolbox can be classified into two groups: one group containing broader qualitative LCM elements; another group containing specific quantitative LCM elements. The first group consists of LCM elements such as LCM strategies, programmes, systems, processes and concepts, while the second group includes LCM tools and techniques and LCM data, information and models (Figure 6.1). The LCM tools and techniques that can be employed for assessing and addressing different aspects of infrastructure planning are broadly divided as procedural and analytical tools.

Figure 6.1 depicts LCM elements within a decision-making framework.

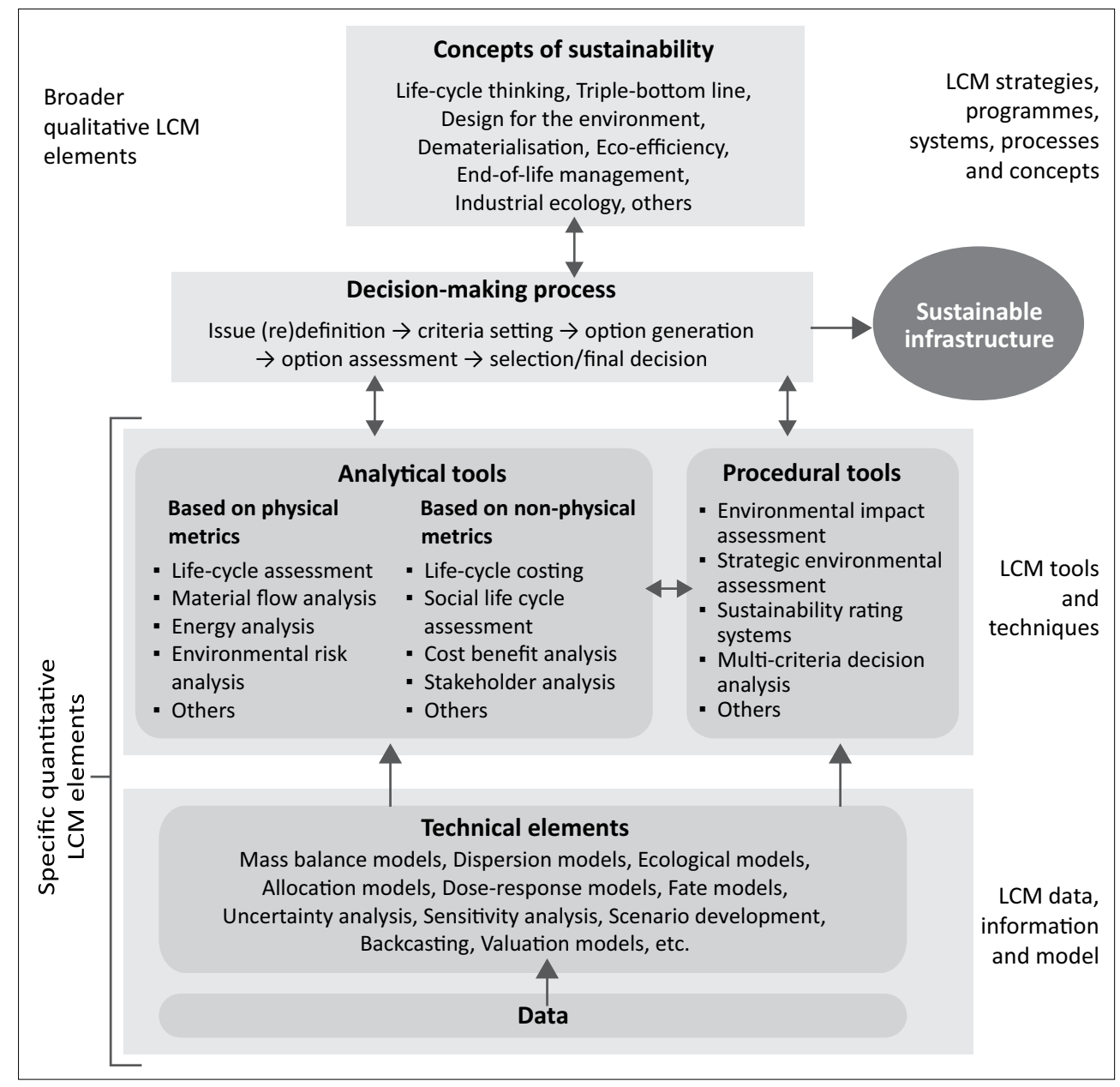

Figure 6.1 LCM elements within a decision-making framework (Source: Diagram based on Wrisberg et al., 2002:36) 
The following sections present the most commonly used procedural and analytical tools for sustainability practice and those that are emerging. The discussion of the tools focuses on applicability, key issues involved and limitations.

\section{Procedural LCM tools for sustainable infrastructure}

This section discusses three procedural tools for sustainable infrastructure, namely strategic environmental assessment (SEA), sustainability rating tools and multicriteria decision-making.

\section{Strategic environmental assessment}

A strategic environmental assessment addresses sustainability issues earlier in the decision process taking the impact assessment upstream into infrastructure planning. Considering a greater scale and longer time interval, SEA focuses on policies, programmes and plans as strategic decisions points. The entry point and how SEA is deployed and for what purpose defines its strategic content and its influence on the decisions, avoiding a non-strategic application of SEA late in the process after significant decisions are made. The strategic advantage of SEA comes from its nesting into the strategic-planning and decision-making processes (Noble \& Nwanekezie, 2017). Capitalising on the experience of legislated SEA in different regions of the world and the requirements of regulatory bodies and financers in Africa, SEA should be applied beneficially in the planning and development of sustainable infrastructure systems in Africa.

\section{Sustainability rating tools}

Rating tools reward options that go beyond the legal, environmental, social and other sustainability minima to achieve distinctive sustainability performance influencing planners to consider the important issues at the most appropriate time. The rating systems are powerful planning tools that can be used to embed sustainable thinking into each decision point in the development of a plan. The tools are also helpful in communicating sustainability in a comprehensible manner to different stakeholders within and outside the planning institutions. The use of sustainability-oriented rating systems for infrastructure systems at the planning stage can be built on the experience of existing rating tools, such as the Civil Engineering Environmental Quality Assessment (UK), the Infrastructure Sustainability Rating Scheme (Australia and New Zealand) and SuRe ${ }^{\circledast}$ (Global). Some are applicable across sectors (e.g., Envision, USA) and others are sectorspecific (e.g., GreenroadsTM, USA and international).

Africa will benefit from the dissemination and application of sustainability infrastructure rating systems adapted to the local contexts and developed through collaborations between planning institutions and universities. 


\section{Multicriteria decision-making}

Planning for sustainable infrastructure that involves many aspects and variables is a subject of multicriteria decision making. Multicriteria decision analysis (MCDA) techniques help in managing decision processes typically characterised by many assessment criteria, alternatives and actions. MCDA is promoted as an appropriate tool to adopt decisions (Janic, 2003; Tudela, Akiki \& Cisternas, 2006) as it provides the opportunity to integrate information about impacts and other factors with the views and opinions of stakeholders and decision-makers (Geneletti, 2005). MCDA techniques are best used as screening tools to refine a shortlist of preferred decisions and plans.

\section{Analytical LCM tools for sustainable infrastructure}

The utility of the procedural tools relies on better information and data that comes from employing analytical tools used in modelling and visualising the triplebottom-line performance of plans and decisions enabling evidence-based decision processes that result in sustainable infrastructure. LCM has the potential to put life-cycle thinking into planning practice using relevant tools that account for the impact of infrastructure not only on the economy but also on the environment and society throughout its full life cycle (Sonnemann, Gemechu, Remmen, Frydendal \& Jensen, 2015).

Some various analytical tools and methods can provide quantitative insight regarding the material and other impact aspects of infrastructure systems. Material flow analysis (MFA) and life-cycle sustainability assessment (LCSA) serve the function of analysing and appraising alternatives of infrastructure planning and development capturing the intricacies of supply chain, the operation and end-oflife management aspects. They can both be used in 'hotspot' analyses that help 'identify potential solutions and prioritise actions around the most significant economic, environmental, ethical and social sustainability impacts or benefits' of infrastructure plans (Barthel et al., 2015). Table 6.4 includes findings of lifecycle assessment (LCA) studies from the literature relevant to different types of infrastructure.

Table 6.4 Findings of life-cycle assessment (LCA) applied to infrastructure systems

\begin{tabular}{|l|l|}
\hline \multicolumn{1}{|c|}{ Attribute } & Typical environmental impact / highlights \\
\hline $\begin{array}{l}\text { Low population } \\
\text { density }\end{array}$ & $\begin{array}{l}\text { Impact potentials from mobility take on increased importance (Heinonen, Kyro \& } \\
\text { Junnila, 2011). Dense urban living reduces per capita transport emissions, but an } \\
\text { increased wealth of inhabitants ultimately results in higher overall consumption and } \\
\text { carbon footprint. }\end{array}$ \\
\hline $\begin{array}{l}\text { Climate variability } \\
\text { (hot summers, } \\
\text { cold winters) }\end{array}$ & $\begin{array}{l}\text { Impacts from space conditioning take on increased importance (Goldstein, Birkved, } \\
\text { Quitzau \& Bauschild, 2013). }\end{array}$ \\
\hline
\end{tabular}




\begin{tabular}{|c|c|}
\hline Attribute & Typical environmental impact / highlights \\
\hline $\begin{array}{l}\text { High population } \\
\text { growth rate } \\
\text { or economic } \\
\text { development }\end{array}$ & $\begin{array}{l}\text { Impacts from capital formation (building and infrastructure construction) take on increased } \\
\text { importance (Goldstein et al., 2013). }\end{array}$ \\
\hline $\begin{array}{l}\text { Compromised } \\
\text { waste } \\
\text { management } \\
\text { system }\end{array}$ & Local impacts take on increased relevance (Goldstein et al., 2013). \\
\hline $\begin{array}{l}\text { Significance of } \\
\text { mobility in life- } \\
\text { cycle assessment } \\
\text { of buildings }\end{array}$ & $\begin{array}{l}\text { To improve urban sustainability, development strategies should consider the transport } \\
\text { infrastructure in addition to building efficiency (Bastos, Batterman \& Freire, 2016). }\end{array}$ \\
\hline $\begin{array}{l}\text { 'Smart-city' } \\
\text { solutions at } \\
\text { the urban } \\
\text { system level }\end{array}$ & $\begin{array}{l}\text { The importance of choosing solutions with the right focus and optimising the design to } \\
\text { best fit the intentions (Ipsen, Zimmermann, Nielsen \& Birkved, 2018). }\end{array}$ \\
\hline $\begin{array}{l}\text { Environmental } \\
\text { assessment in } \\
\text { land planning }\end{array}$ & $\begin{array}{l}\text { The life-cycle assessment (LCA) framework can be adapted to environmental assessment } \\
\text { in land planning and has the potential to provide relevant information in decision-making } \\
\text { processes (Bistrup et al., 2015; Loiseau, Roux, Junqua, Maurel \& Bellon-Maurel, 2013). } \\
\text { Qi, Zhang, Jiang, Hou and Li (2019) adapted the existing territory LCA method to } \\
\text { highlight regional characteristics in urban territories and applied the improved method to } \\
\text { a Chinese city. }\end{array}$ \\
\hline $\begin{array}{l}\text { Sprawling } \\
\text { and compact } \\
\text { neighbourhoods }\end{array}$ & $\begin{array}{l}\text { Occupant transportation phase plays a highly important role in neighbourhood } \\
\text { performance. Neighbourhood development assessment should consider several } \\
\text { variables beyond cumulative energy demand (CED) and costs (Sosa, Espinoza, Royo } \\
\& \text { Gálvez, 2017). }\end{array}$ \\
\hline $\begin{array}{l}\text { Sustainable } \\
\text { buildings }\end{array}$ & $\begin{array}{l}\text { Active participation by the regional government and by various authorities and institutions } \\
\text { in the region is a key success factor in fostering a life-cycle management (LCM) approach } \\
\text { in the building sector. Active participation by and support of industry federations and } \\
\text { trade associations are also vital as smaller companies - a strong feature of the building } \\
\text { sector - rely heavily on their advice and guidance. Above all, a dedicated project team is } \\
\text { essential to start the process and then to coordinate the various actions until all partners } \\
\text { operate with confidence with LCM (Adibi, Darul, Pasquest, Demaretz \& Traisnel, 2017). }\end{array}$ \\
\hline $\begin{array}{l}\text { Planning of water } \\
\text { and wastewater } \\
\text { systems }\end{array}$ & $\begin{array}{l}\text { Slagstad and Brattebø (2014) examined the system-wide life-cycle potential } \\
\text { environmental impact of operating a city's water and wastewater system. }\end{array}$ \\
\hline Waste & $\begin{array}{l}\text { Landfilling is usually found in most LCA studies as the least preferred municipal solid } \\
\text { waste management (MSWM) option. The strong dependence of each solid waste } \\
\text { management system (SWMS) on local conditions, such as waste composition or energy } \\
\text { system, prevents a meaningful generalisation of the LCA results as we find it in the waste } \\
\text { hierarchy. It is recommended that stakeholders in solid waste management regard LCA } \\
\text { as a tool, which, by its ability to capture the local specific conditions in the modelling of } \\
\text { environmental impacts and benefits of an SWMS assists them to identify critical problems } \\
\text { and propose improvement options adapted to the local specificities. }\end{array}$ \\
\hline $\begin{array}{l}\text { Roads and } \\
\text { pavements }\end{array}$ & $\begin{array}{l}\text { LCA studies that have in some way estimated the energy use due to traffic have } \\
\text { concluded that the energy used for construction, operation and maintenance of the } \\
\text { infrastructure only amounts to a small part of the energy use for traffic. A conclusion } \\
\text { of this is that if the purpose is to make road transports more energy efficient it can be } \\
\text { better to accept higher energy use for the infrastructure if it leads to lower fuel use } \\
\text { of vehicles since it can result in lower total energy use (Carlson, 2011). A proposed } \\
\text { GIS-based approach shows promising results for usage in LCA at an early stage of road } \\
\text { infrastructure planning (Karlsson et al., 2017). }\end{array}$ \\
\hline
\end{tabular}




\begin{tabular}{|c|c|}
\hline Attribute & Typical environmental impact / highlights \\
\hline $\begin{array}{l}\text { Electricity } \\
\text { generation } \\
\text { technologies }\end{array}$ & $\begin{array}{l}\text { Direct emissions from plant operation represent the majority of the life-cycle emissions } \\
\text { for fossil fuel technologies, whereas fuel provision represents the largest contribution for } \\
\text { biomass technologies and nuclear power; infrastructures provided the highest impact } \\
\text { for renewables. These data indicated that all three phases should be included for } \\
\text { completeness and to avoid problem shifting. The most important technological aspects } \\
\text { were identified as the energy recovery efficiency and the flue gas cleaning system for } \\
\text { fossil fuel technologies; the electricity mix used during both the manufacturing and the } \\
\text { construction phases for nuclear and renewable technologies; and the type, quality and } \\
\text { origin of feedstock, as well as the amount and type of co-products, for biomass-based } \\
\text { systems (Turconi, Boldrin \& Astrup, 2013). }\end{array}$ \\
\hline $\begin{array}{l}\text { Renewable energy } \\
\text { development }\end{array}$ & $\begin{array}{l}\text { - Renewable energy technologies show clear environmental advantages compared } \\
\text { to fossil fuel alternatives, including a substantial decrease in life-cycle greenhouse } \\
\text { emissions of grid electricity as well as a decrease in the extraction of fossil resources. } \\
\text { Renewable energy substantially reduces impacts on the environment and human health, } \\
\text { with the exception of material use (UNEP, 2015). There is a need to systematically } \\
\text { examine end-of-life issues and ensure recycling of products, a responsibility that may } \\
\text { fall disproportionately on local and regional authorities. } \\
\text { - Wind power often emerges as the renewable technology with the lowest overall } \\
\text { environmental impact (Hertwich et al., 2015). }\end{array}$ \\
\hline
\end{tabular}

\section{Material flow analysis}

Infrastructure development and management play a significant role in the movement of materials and their temporary and permanent sequestration. Knowledge-driven guidance on decisions about the type, form, quantity and specific location of materials used in the construction of infrastructure systems, and what happens to the materials at the end of the lifetime of the structure is important in identifying interventions and engaging relevant life-cycle actors. In urban areas where most of the infrastructure systems are concentrated, tracking and understanding the flow and stock of materials, such as steel and concrete, is crucial for resource-efficient planning (e.g., Kennedy et al., 2015).

Material flow analysis is the earliest urban metabolism method whereby single material flows or more comprehensive lists of metabolic outflows (e.g., food, water and fuels) have been accounted for one year through cities, regions and nations. MFA should be beneficially applied at the level of the national or subnational level where the plan or the strategic decision around infrastructure is envisaged to be implemented. UNEP (2013) made the case for examining cities using material flows and recommended that cities can be restructured from a materials perspective and their infrastructure reconfigured to improve resource productivity and reduce environmental impacts. Ioppolo, Cucurachi, Salomone, Shi and Yigitcanlar (2019) proposed the integration of the mandatory procedural tool of SEA and the voluntary analytical tool of MFA, which can generate a new framework for sustainable development planning. 


\section{Life-cycle sustainability assessment}

Life-cycle sustainability assessment (LCSA) is composed of environmental life-cycle assessment (LCA), economic life-cycle costing (LCC) and social lifecycle assessment (S-LCA). There is an important utility in using LCA, LCC and S-LCA elements of LCSA to capture environmental, economic and social lifecycle bottom lines throughout the life cycle of the infrastructure. The life-cycle thinking empowers the decision-makers with new opportunities of larger spans of optimisation that will, in turn, empower designers to harvest synergies and improvements by using tools and approaches of design for disassembly, design for repair, design for deconstruction and design for recycling. LCA, for example, can be employed to calculate an impact footprint of the different alternatives of planning using simplified LCA tools that generate impact results, such as global climate change, with the help of generic life-cycle inventory database to identify hotspots and trade-offs. Beyond the traditional application of LCA as a productoriented methodology, a new LCA-based approach called 'territorial LCA' has gradually emerged to assess geographically or administratively defined systems (Loiseau et al., 2018) which would be relevant in analytical aspects of planning for sustainable infrastructure.

The economic bottom line assessed through LCC is broader than the traditional bottom line considered in current accounting systems and planning systems. Costs in LCC can be presented from the perspective of a predefined stakeholder, such as a manufacturer, a user, or society at large. Taking the societal perspective during decision making and strategic planning of infrastructure systems is both pragmatic and beneficial. LCA and S-LCA can respond in an enhanced way to the explicit requirements imposed by financiers and regulatory bodies on the environmental and social aspects of planning respectively.

\section{Key policy and strategic issues for African countries}

The megatrends of urbanisation and population growth in the African region have critical policy implications. First, as the region urbanises, policymakers must plan for resource-efficient and inclusive urban infrastructure development that can yield multiple co-benefits. Second, the African region must think strategically about urban infrastructure across a range of diverse city sizes: small, medium and large. Third, early and anticipatory infrastructure planning efforts at multiple levels of government - the national, regional and city levels - are needed to guide the sustainable development of these rapidly growing and urbanising areas from the outset to address many of the urbanisation challenges. It is becoming increasingly important to include the right sustainability and resilience aspects into the planning and development of infrastructure systems. 
Infrastructure planning and development in Africa faces several constraints. These include geographical constraints, deficiencies in planning, fragmented planning, institutional inefficiencies, regulatory bottlenecks, and a lack of planning and implementation skills. Key measures to address these challenges should consist of the following elements:

Articulating national strategies and leadership for sustainable infrastructure: Aligning policy goals across and within various levels of government including a clear long-term vision and targets for sustainable infrastructure.

\section{Strengthening urban planning linked with integrated infrastructural} planning: Promoting and employing integrated infrastructure planning that goes beyond sectoral silos.

Institutional capacity building and reform: Building human and institutional capacity and providing adequate tools to planners and designers.

Increasing access to LCM skills: Creating new programmes and strengthening existing curriculums.

Partnerships, knowledge management and community engagement:

Encouraging collaborations and participation.

\section{Articulating national strategies and leadership for sustainable infrastructure}

There is a need for national authorities to clearly articulate a clear and comprehensive national strategy for sustainable infrastructure and embed it in an overall policy strategy for sustainable and inclusive growth and development. Ideally, a single integrated strategy for low-carbon, resource-efficient, climateresilient and sustainable development should map to national and local planning and sector plans to guide investments. Countries need to adopt the principle of sustainable infrastructure as a national policy in all planning processes. This policy would be supported by strategies in key infrastructure sectors with clear longterm goals to incentivise the implementation of sustainability practices. Such an integrated strategic framework:

ensures coherence across public policy actions and investments;

facilitates coordination across sectors and levels of government; and

provides the clarity and confidence needed by investors.

Leadership is required for the development of a long-range strategic plan for sustainable infrastructure founded on well-understood national and local aspirations and aligned with the UN SDGs and the nationally determined contributions derived 
from the Paris Climate Agreement. A top-down approach to sustainable infrastructure planning maintains the focus on broader and strategic policy objectives in helping form a strategic view on where investments needs are most pressing. Providing stable long-term direction to infrastructure investment whilst retaining the flexibility needed to deal with uncertainty over long horizons is critical.

African countries need to consider setting up national bodies similar to the UK National Infrastructure Commission aimed at providing the government with independent expert advice on major infrastructure challenges and developing a strategic framework for planning major investments beyond the timeframe of electoral cycles. These national bodies can be tasked to undertake a national infrastructure assessment; make recommendations to the government and then hold the government to account on implementation; produce reports, independent of government and all stakeholders, based on rigorous evidence; and identify entry points and mechanisms to allow for the greatest impact of sustainable infrastructure.

Addressing fundamental price distortions for natural resources and infrastructure services, such as fossil fuel subsidies and the lack of carbon pricing, is also key to improving the public policy environment for sustainable infrastructure. In avoiding a bias of infrastructure investment toward high-carbon sources of energy, favouring unsustainable infrastructure and undermining efficiency in energy use, appropriate government actions are needed to address negative incentives and externalities. Tools based on life-cycle thinking are needed to integrate sustainability-related aspects into the planning and decision-making process. Governments need to ensure that such tools and standardised approaches for the implementation of the sustainable infrastructure policy are available in the public sector and utilities and understood by the private sector so that they contribute to benchmarking and create a common language among all stakeholders.

\section{Strengthening urban planning linked with integrated infrastructural planning}

Urban planning needs to guide urban expansion and the associated infrastructure should be strengthened to reduce sprawl, enhance densification and prevent development in precarious environmental zones. New urban planning aimed at lowering infrastructure costs and increasing density can help address the issue of productivity costs and can reduce the urban sprawl that is putting pressure on agricultural land and the environment.

Using the concept of a compact city, offered as an alternative to urban sprawl and adopted as policy by some countries, strategic spatial plans linked to infrastructure development can promote more compact forms of urban expansion focused around public transport (UN Habitat, 2009). An infrastructure plan is a key element of 
such strategic spatial plans where transport and land-use linkages are the most important taking precedence over other forms of infrastructure such as water and sanitation trunk infrastructure that follows (UN Habitat, 2009). The integration of land use and transport planning can be improved through the earliest possible definition of land-use needs for new and future infrastructure corridors and sites, followed by adequate land-use control and acquisition. Without integrated planning that promotes sustainability principles and coordination between different infrastructure sectors, infrastructure will likely be a source of negative environmental and social impacts over the coming decades and opportunities will be lost for synergistically advancing the SDGs and sustainable economic growth. Planners could use checklists to assist them in developing proactive collaboration for infrastructure planning. Barriers to integrated infrastructure planning must be addressed. These include insufficient institutional capacity, lack of expertise, and political and cultural challenges at the national level.

\section{Institutional capacity building and reform}

The provision of 'hard' infrastructure can be significantly constrained by weak 'soft' infrastructure such as institutions and capabilities. The institutional capacity of African countries to develop robust infrastructure plans and implement them is fundamental in facilitating sustainable infrastructure investments. Deficient institutional capacity leads to wrong planning and jeopardises the achievement of commitments such as the UN SDGs and NDCs. There is a need for more awareness-raising activities on sustainable infrastructure to shift the policymakers' mindset in understanding and embracing the sustainable infrastructure imperative, and accelerating the development and standardisation of appropriate frameworks and tools. There is also a need for institutional reform by governments as part of the efforts of building the capacity to develop and communicate long-term sustainable infrastructure plans that eventually lead to a pipeline of bankable infrastructure projects for investors.

A key challenge is to develop capacity and practice to systematically incorporate climate risks and sustainability criteria into the long-term infrastructure plans. In addition to capacity-building courses for practising planners and related professionals, efforts should also be focused on stimulating inter-agency and inter-ministerial coordination (through a supra-ministerial coordination unit) and communication in developing and implementing infrastructure plans that overcome silo thinking and reap synergies among different infrastructure plans and systems. There is a need to build institutional capacity for sustainability assessment by incorporating it into line agencies supported by in-house life-cycle management experts or by relevant independent professional associations. 
Part of the institutional reform and capacity building efforts is learning from experiences in other countries with some best practices of planning. Boxes 6.1 and 6.2 provide summaries of best practices of planning from a developed country. The exemplary work from the city of Bogotá is shown in Box 6.3 as an example of best practice from the developing world.

\section{Box 6.1: Integrated vision in brownfield development in Sweden}

Hammarby Sjöstad is a district in Stockholm that has been under development for years. It is an old brownfield of industrial area that has been transformed into a sustainability model residential and commercial area visited by many local and international visitors. Its success story can be traced to the integrated view of the energy, transport and waste management infrastructure which was realised as it was considered from the outset during the planning process taking relevant stakeholders on board early. Gu, Vestbro, Wennersten and Assefa (2009) underscored how the planning dealt with conflicts of interest and multiple objectives such as technical, social, practical, economic and aesthetic objectives. Planning decisions were not left to planners from Stockholm's office of city planning only. The planning team included people from the office of environment and those municipal entities responsible for roads and real estate, energy, water and waste (Kasioumi, 2011). The planning process is highlighted as proactive, visionary, collaborative and communication-intensive where planners were helped by national planning systems while using the neighbourhood plans to ensure attributes of 'containments, compactness, environmentally-friendly design, green space, and public transit'(Kasioumi, 2011. It was emphasised that an integrated vision of interrelated goals is an important starting point. As reported by Berger (2017a), Hammarby Sjöstad's higher upfront cost associated with energy and resource-efficiency investments was justified based on the life-cycle cost analyses used to guide planning and investment decisions under the direction of Stockholm's planning and development administration. The process behind HS involved 'thorough analytical work, comprehensive planning, sound public policies, adequate financing, and management controls tied to specific deadlines and deliverables' (Berger, 2017a: para. 28).

\section{Box 6.2: Performance target and collaborative process in Sweden}

The Stockholm Royal Seaport (SRS) is in another part of Stockholm that builds on the experience of planning and developing Hammarby Sjöstad. The integrated view of infrastructure has gone even further in accommodating different scenarios in the planning process. It aims at reducing the per capita carbon dioxide emission to 1.5 tonnes per person per year which is compatible with the global cap of $2^{\circ} \mathrm{C}$ based on the Paris Agreement. The reason for the success story of Hammarby Sjöstad, and later picked up SRS, was attributed to the development of a guiding plan or programme that from the outset outlined the vision, goals and objectives. In the SRS case, its environmental and sustainability programme contains climate-adapted and green outdoor environment, sustainable energy systems, sustainable recovery systems, sustainable water and wastewater systems, sustainable transport, environmentally-adapted residential and commercial premises, sustainable lifestyles and sustainable businesses.

(continued on next page) 
The programme was developed through a collaborative process that involved five of Stockholm city's departments (city planning, city development, planning, city environment, city traffic and local district administration), developers and construction companies, energy, water, waste service providers and academia (Holmstedt, Brandt \& Robèrt, 2017).

\section{Box 6.3: Bus Rapid Transport and land use in Colombia}

Bogotá is perceived as an interesting case when considering urban issues. The positive changes experienced by this city of eight million people in just a decade have raised international interest from policymakers, researchers and multilateral institutions. The perception about Bogotá changed from an example of a failed city to an example of a sustainable and promising one. The main symbol of this change is indisputably the Bus Rapid Transit (BRT) system called TransMilenio. It is widely recognised as one of the world's best systems, with high-capacity, high-quality buses that make 1.6 million passenger-trips daily. TransMilenio has also influenced other aspects of Bogotás structure and life, such as land use, productivity, road fatalities, and even crime and health issues. However, the mutual impacts between land use and transport in Bogotá during the past two decades have also been influenced by other elements such as the creation of a regulatory framework for urban planning that provided new public instruments, an improvement of local institutions, a transport policy that prioritised public transport over car infrastructure, and a political and economic context that promoted a dense, transit-oriented city. For a number of developing cities in a similar situation, Bogotá is an interesting example. In terms of land use/transport links, it serves as a rare and quite useful 'laboratory', as it enables the evaluation of changes after a new mass transit system was introduced in the main corridors of the city (Bocajero \& Tafur, 2013:3).

\section{Increased access to LCM skills}

The use of life-cycle concepts and tools at the national level in Africa is non-existent or very limited due to the lack of a capable workforce and limited availability of databases (Machado \& Cavenaghi, 2009). They are yet to be incorporated and acknowledged, through scientific research, educational programmes, business practices and national policies. There is a need to reform existing and developing new curricula in many engineering and planning schools in Africa where the education and training programmes have not kept up with challenges of supporting sustainable infrastructure planning and development. Engineering schools need to provide future engineers and technicians with the knowledge, tools and techniques that they need to design, build and manage sustainable infrastructure and to take a leadership role in making infrastructure sustainable. Courses that prepare engineers to interpret/employ life-cycle management within decision-making processes will fill the current knowledge and skills gap in professions relevant to sustainable infrastructure. Planning schools should embrace innovative planning ideas with an increased focus on skills in participatory planning, communication and negotiation, 
and LCM strategies, programmes, systems, processes and concepts. There should be a more systematic approach to the education of infrastructure professionals on LCM tools and techniques and a strengthening of the research community concerning LCM. The development of LCM analysts as a new profession should be considered in training professionals with a basic understanding of infrastructure planning and development. In the interim, the necessary capacity and skillsets to influence future planners can be developed through the integration of LCM-related subjects in disciplines such as economics.

Expanding and improving technical vocational education and training (TVET) programmes in Africa can play an important role in filling the skills gap in sustainable infrastructure development in the continent. Better-quality TVET programmes with better alignment with skills demand in the sector and well-designed job placement programmes upon graduation can be used to improve the role of TVET in lowering youth unemployment while creating sustainable infrastructure. A complementary action is the strengthening of professional organisations and international professional networks to offer continuous professional development courses on sustainable infrastructure. Potential drivers for mainstreaming LCM application, such as environmental labelling schemes and green procurement, need to be developed and expanded building on lessons learned from experiences in Europe and North America.

\section{Partnerships, knowledge management and community engagement}

Efficient policy planning, design and implementation, which drives sustainable infrastructure development, should rely on integrated and participatory approaches. This implies not only alignment of the objectives of the various policies (e.g., industrial, trade and infrastructure), but also dynamic consultations between all relevant stakeholders including government agencies, the private sector, academia, local communities and regional and international partners. In tapping into the comparative advantages of each entity, better coordination and collaboration between national and regional programmes are needed for the successful development of cross-border infrastructure systems such as transport and energy corridors, aiming at fostering regional integration. Local authorities should encourage collaboration internally across departments, and externally with national government agencies.

A key to successful planning and development of sustainable infrastructure is sharing knowledge and experiences among specialists. Web-based knowledge platforms on sustainable integrated infrastructures can be developed to help promote better engagement, function as a one-stop-shop for easily accessible and 
reliable information and become a forum for contributing ideas and solutions. Good infrastructure relies on and enables effective governance whereby people are informed of developments around them and are supportive of them. Visioning is an important early step in developing a holistic strategy for infrastructure planning Visioning can provide opportunities to educate the community on how infrastructure systems work and how factors such as changing technology, climate change, and resource management affect our ability to create and maintain sustainable infrastructure systems. Community engagement is essential in identifying acceptable alternatives that reduce demand on infrastructure systems and exploring all options before spending money in planning and developing larger systems.

\section{A framework for strategic planning of sustainable infrastructure in Africa}

A framework that can create a collaborative platform for key professionals to work in an integrated manner in infrastructure planning is proposed. This framework is aimed at ensuring that sustainability is a planned outcome of an integrated approach, not a random add-on result. The framework is for use by planners, decision-makers and policymakers at the highest levels of national and subnational bodies relevant for the planning and operation of infrastructure systems. The framework is based on the following principles:

1. Forming broader long-term plans through a strategic planning approach instead of a piecemeal approach.

2. Employing a comprehensive life-cycle perspective instead of a limited perspective.

3. Adopting a shared vision of sustainable infrastructure based on a common understanding of explicitly-articulated performance criteria among stakeholders that have traditionally functioned in silos.

4. Considering nature-based solutions in the provision of infrastructure services.

5. Adapting infrastructure systems to climate change and extreme events.

The framework seeks to achieve the following objectives:

1. To involve public authorities, utility companies, planners, engineers and other affected stakeholders starting from the early stages of the planning phase.

2. To measure the value of sustainable infrastructure and its sustainability benefits throughout the planning phase. 
3. To weigh the full benefits and costs of options that achieve the intended outcome over the life cycle of the infrastructure systems.

4. To create and strengthen capacity at relevant levels of government and industry and enable expertise alignment to deliver on sustainable infrastructure.

5. To create economic incentives for sustainable infrastructure that drives innovation.

6. To educate, engage and inspire public support for sustainable infrastructure.

\section{The structure and content of the framework}

The framework provides for use of the different elements of the LCM ecosystem in enabling decision making for sustainable transformation of infrastructure sectors in the face of future uncertainty and rapid changes. The LCM elements help in screening and mapping the different trade-offs faced in developing 'more sustainable' infrastructure (Truffer, Störmer, Maurer \& Ruef, 2010). They facilitate transparent and reflexive communication while not covering all aspects of the overall strategy-making process. Infrastructure planning happens at several levels depending on the kind of infrastructure and the functions devolved to the different departments, national agencies and subnational spheres of government. A life-cycle approach should underpin planning and decision-making. The ability to influence the life-cycle economic, social and environmental impact is greatest during the earliest stages when sustainability goals are formulated. Figure 6.2 depicts the framework for a collaborative platform for the integration of sustainable infrastructure planning functions at national and local levels and the application of different elements of LCM detailed in Table 6.5. 


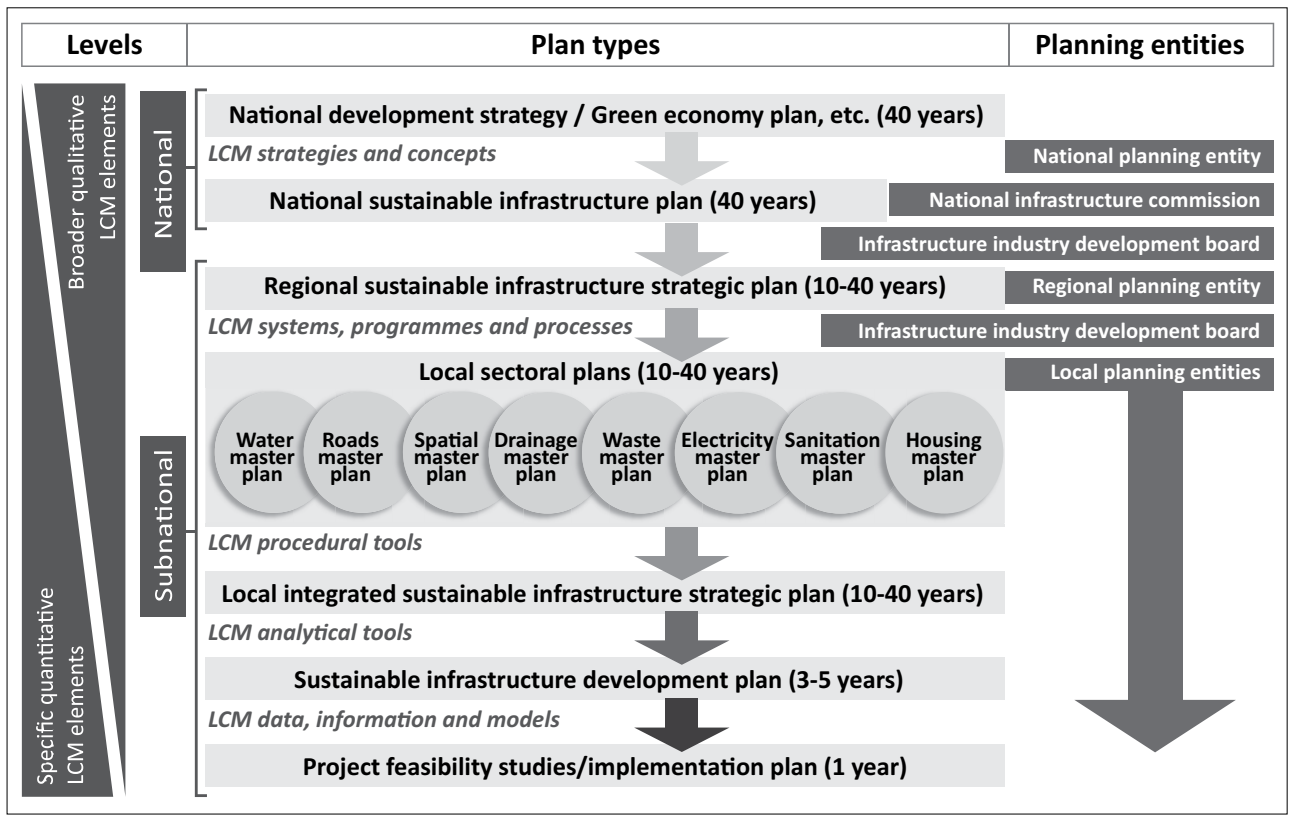

Figure 6.2 Framework of sustainable infrastructure planning and the role of LCM elements

Table 6.5 Cascading from national to local planning and LCM elements

\begin{tabular}{|c|c|c|c|c|}
\hline \multicolumn{3}{|c|}{ Level of planning } & $\begin{array}{l}\text { Time } \\
\text { frame }\end{array}$ & $\begin{array}{l}\text { LCM elements for sustainable } \\
\text { infrastructure }\end{array}$ \\
\hline \multirow[t]{4}{*}{ National } & \multirow[t]{4}{*}{ Macro } & $\begin{array}{l}\text { National development strategy/ } \\
\text { Green economy plan }\end{array}$ & \multirow[t]{7}{*}{$10-40$ years } & \multirow{4}{*}{$\begin{array}{l}\text { - Mainly broader qualitative LCM } \\
\text { elements } \\
\text { - Visioning } \\
\text { - Scenario planning }\end{array}$} \\
\hline & & National sector planning & & \\
\hline & & National spatial development plan & & \\
\hline & & National infrastructure commission & & \\
\hline \multirow[t]{3}{*}{ Provincial } & \multirow[t]{7}{*}{ Meso } & $\begin{array}{l}\text { Provincial growth and development } \\
\text { strategy }\end{array}$ & & \multirow[t]{3}{*}{$\begin{array}{l}\text { - A mix of broader qualitative and } \\
\text { specific quantitative LCM elements }\end{array}$} \\
\hline & & $\begin{array}{l}\text { Provincial spatial development } \\
\text { strategy }\end{array}$ & & \\
\hline & & Provincial sector planning & & \\
\hline \multirow[t]{5}{*}{ Local } & & Local development strategic plan & \multirow[t]{2}{*}{ Ongoing } & \multirow{4}{*}{$\begin{array}{l}\text { - A mix of broader qualitative and } \\
\text { specific quantitative LCM elements } \\
\text { - Sustainable infrastructure } \\
\text { rating tools } \\
\text { - Planning guidelines for sustainable } \\
\text { integrated infrastructure in cities }\end{array}$} \\
\hline & & Local spatial development plan & & \\
\hline & & Local sector master plans & $10-40$ years & \\
\hline & & $\begin{array}{l}\text { Local medium-term integrated } \\
\text { development plan }\end{array}$ & 5 years & \\
\hline & Micro & $\begin{array}{l}\text { Project feasibility studies and } \\
\text { implementation }\end{array}$ & 1 year & $\begin{array}{l}\text { - Mainly specific quantitative LCM } \\
\text { elements } \\
\text { - Sustainable infrastructure rating } \\
\text { tools } \\
\text { - Sustainable procurement } \\
\text { programmes } \\
\text { - Safeguards }\end{array}$ \\
\hline
\end{tabular}

Life-cycle management for sustainable infrastructure planning ... $\quad 215$ 


\section{Applying the framework: Planning process, assessment and institutional architecture}

In applying the proposed framework, there are five conditions for success that should be fulfilled by the supporting tools: (i) covering the full life cycle of infrastructure systems, (ii) covering all components of the triple bottom line, (iii) enabling the engagement of life-cycle stakeholders, (iv) accounting for important material aspects, and (v) employing rating systems. To this end, life-cycle management-oriented adaptive strategic planning process; strategic environmental assessment with a life-cycle sustainability assessment content; and life-cycle management driven institutional architecture are important.

\section{LCM-driven adaptive strategic planning process}

The first step of the process is preliminary consideration of objectives, constraints and available options with respect to the analysis of the existing situation. This step includes enumerating conditions for success and specifying desirable outcome to be included in a base plan. Then an iterative process of incorporating a series of additional targeted actions, such as 'mitigating actions', 'hedging actions', 'seizing actions' and 'shaping actions', are incorporated in refining the base plan to a final plan (Kwakkel, Walker \& Marchau, 2010). These actions are included as part of the plan to proactively deal with vulnerabilities, seize opportunities and shape external forces. The iteration includes analysis of the base plan and an inadvance identification of opportunities that will improve the plan's success and vulnerabilities that cause the plan to fail.

Table 6.6 provides an example of these drivers of actions (vulnerabilities, opportunities and external condition) for an energy plan.

Table 6.6 Actions for the refinement of a base plan: An example of an energy plan for expanding access using a modular renewable energy system based on domestically manufactured technologies

\begin{tabular}{|l|l|l|l|}
\hline \multicolumn{1}{|c|}{ Actions } & Driver & Examples of drivers & Action (example) \\
\hline $\begin{array}{l}\text { Mitigating } \\
\text { action }\end{array}$ & Certain vulnerabilities & Climate change & Include climate-resilient element \\
\hline $\begin{array}{l}\text { Hedging } \\
\text { actions }\end{array}$ & Uncertain vulnerabilities & Technology change & $\begin{array}{l}\text { Plan element that responds to a } \\
\text { range of changes }\end{array}$ \\
\hline $\begin{array}{l}\text { Seizing } \\
\text { actions }\end{array}$ & Certain opportunities & $\begin{array}{l}\text { New university programmes on } \\
\text { renewable energy }\end{array}$ & $\begin{array}{l}\text { Include actions that will utilise the } \\
\text { graduates }\end{array}$ \\
\hline $\begin{array}{l}\text { Shaping } \\
\text { actions }\end{array}$ & $\begin{array}{l}\text { External conditions } \\
\text { or events }\end{array}$ & Low level of public awareness & Increase awareness by marketing \\
\hline
\end{tabular}

The refined base plan should also include a list of signposts to be monitored once the plan is implemented. The purpose of the monitoring system to be included as part of the plan is to trigger 'defensive actions', 'corrective actions', 'capitalising 
actions' and 'reassessment' depending on the type of threshold of the monitored signposts reached (Kwakkel et al., 2010). Defensive and corrective measures deal with actions that can lead to keeping or adjusting the implemented plan respectively. Capitalising measures are taken to utilise opportunities that come up with the goal to further enhance the performance of the implemented plan. The monitoring system that can trigger responsive actions is put in place to make the plan an adaptive plan that consists of the planned adaptations and a triggering monitoring system.

Table 6.7 depicts an example of an energy plan with signposts that are monitored during the implementation of the plan.

Table 6.7 Actions for adapting a plan under implementation: Example of an energy plan for expanding access using a modular renewable energy system based on domestically-manufactured technologies

\begin{tabular}{|l|l|l|l|}
\hline $\begin{array}{l}\text { Actions for } \\
\text { refinement } \\
\text { of base plan }\end{array}$ & Signpost types & Example of signposts & Action examples (Outcome) \\
\hline $\begin{array}{l}\text { Defensive } \\
\text { actions }\end{array}$ & $\begin{array}{l}\text { Triggers that don't } \\
\text { require adjusting plan }\end{array}$ & Public acceptance issues & $\begin{array}{l}\text { Conduct clarification activities (plan } \\
\text { remains unchanged) }\end{array}$ \\
\hline $\begin{array}{l}\text { Corrective } \\
\text { actions }\end{array}$ & $\begin{array}{l}\text { Triggers that require } \\
\text { adjusting the plan }\end{array}$ & Change in demand pattern & $\begin{array}{l}\text { Resize the system by adding or } \\
\text { reducing modules (the plan is } \\
\text { adjusted) }\end{array}$ \\
\hline $\begin{array}{l}\text { Capitalising } \\
\text { actions }\end{array}$ & Opportunities & $\begin{array}{l}\text { Better technology available } \\
\text { at lower cost }\end{array}$ & $\begin{array}{l}\text { Take advantage by using the new } \\
\text { technology (improved performance } \\
\text { of plan) }\end{array}$ \\
\hline Reassessment & $\begin{array}{l}\text { Critical analysis and } \\
\text { assumptions behind } \\
\text { the plan no more valid }\end{array}$ & $\begin{array}{l}\text { Domestic capacity didn't } \\
\text { develop }\end{array}$ & $\begin{array}{l}\text { Consider imported technology is } \\
\text { possible (significant change to the } \\
\text { plan, discarded plan, new plan) }\end{array}$ \\
\hline
\end{tabular}

Each step of the iterative process of developing the final plan will be informed by different elements of LCM with the goal of supporting a strategic planning process that enhances the prospects for sustainable transitions in infrastructure sectors. The planning process is based on the recognition of multiple futures and multiple types and sources of uncertainty, such as demand, technological, climate change, demographic and lifestyle. The adaptive planning process that emanates from the proposed framework outlined requires close collaboration between planners and LCM analysts during the steps of analysis of characteristics of the infrastructure system (e.g., challenges), identification of key contextual factors, assessment of the scope of uncertainties of the future, iterative combination of possible future contextual conditions, identification of options for future technological and organisational configurations, assessment of the strengths and weaknesses, ranking of the options relative to specific stakeholder preferences, synthesis of resulting assessment, presentation of plans and recommendations to decision-makers and stakeholders (e.g., Truffer et al., 2010). 
The participatory element of the planning process enables exposition of contradicting interests and trade-offs involved in the fulfilment of multiple sustainability objectives (Malekpour, Brown \& de Haan, 2015). The overall purpose is to support greater integration of different social and natural science disciplines in a strategic planning process through multi-faceted input and engagement to be coordinated by LCM analysts.

\section{SEA with a life-cycle sustainability assessment content}

Exploring the environmental, economic and social bottom lines - collectively called the triple-bottom-line of infrastructure development - within a SEA frame using life-cycle sustainability assessment can unleash a broader range of synergies that would otherwise be left untapped. Diagnostic tools of LCSA to carry out analysis feed into operational frameworks of strategic planning and decisionmaking using the SEA vehicle to take the planning practice to new modes of operation. The simultaneous running of the planning process and the SEA process iteratively assesses, finds alternatives and optimises solutions that will continuously make up the final plan (Bidstrup \& Hansen, 2014). SEA with a life-cycle sustainability assessment content enables the advantage of the analytical capability of the quantitative and qualitative tools in providing life-cycle insights. As outlined in Bidstrup and Hansen (2014), within the process of undertaking SEA, insights from LCA and S-LCA can, for example, be used to inform and support a significant number of the basic elements of legislated SEA.

Higher elements of LCM are more practical for use at the higher and broader level of the national planning process. The analytical tools can also be applied at the same level to broadly assess the alternatives using established databases and indicator sets. At this stage, generic LCA databases such as Ecoinvent can, for example, be used for the environmental life-cycle part, while S-LCA databases such as PSILCA can serve the same purpose for the social life-cycle impacts. Enriching the planning process with the LCM elements offers a better understanding of the material and non-material components of the infrastructure and in teasing out the different subsystems and the interactions between them. The approach that expands the system boundary beyond the conventional elements provides opportunities for understanding synergies and multiple possibilities of linkages by identifying opportunities in renovating existing infrastructure systems and in developing and implementing new plans. Red-flagging areas of concern well in advance enables planning effective and timely mitigation and adaptation measures. The approach also allows for experimenting with the implication of alternative pathways and reflexive iteration and adaptation of alternatives. 
The LCM elements can be introduced in varying dosages at different entry points before and after the potential strategies are drafted (see Figure 6.3). For example, generic social and environmental databases and available off-the-shelf environmental product declarations on major products can be utilised at the stage of identifying strategic issues well before developing the strategies by screening out underperforming alternatives based on generic comparisons. This will help shape the iterative drafting and evaluation of candidate strategies through quick and dirty studies. Once a draft list of specific strategies is on the table, the generic databases can be complemented with environmental and social data that can be collected from primary sources to make a final evaluation of specific strategies.

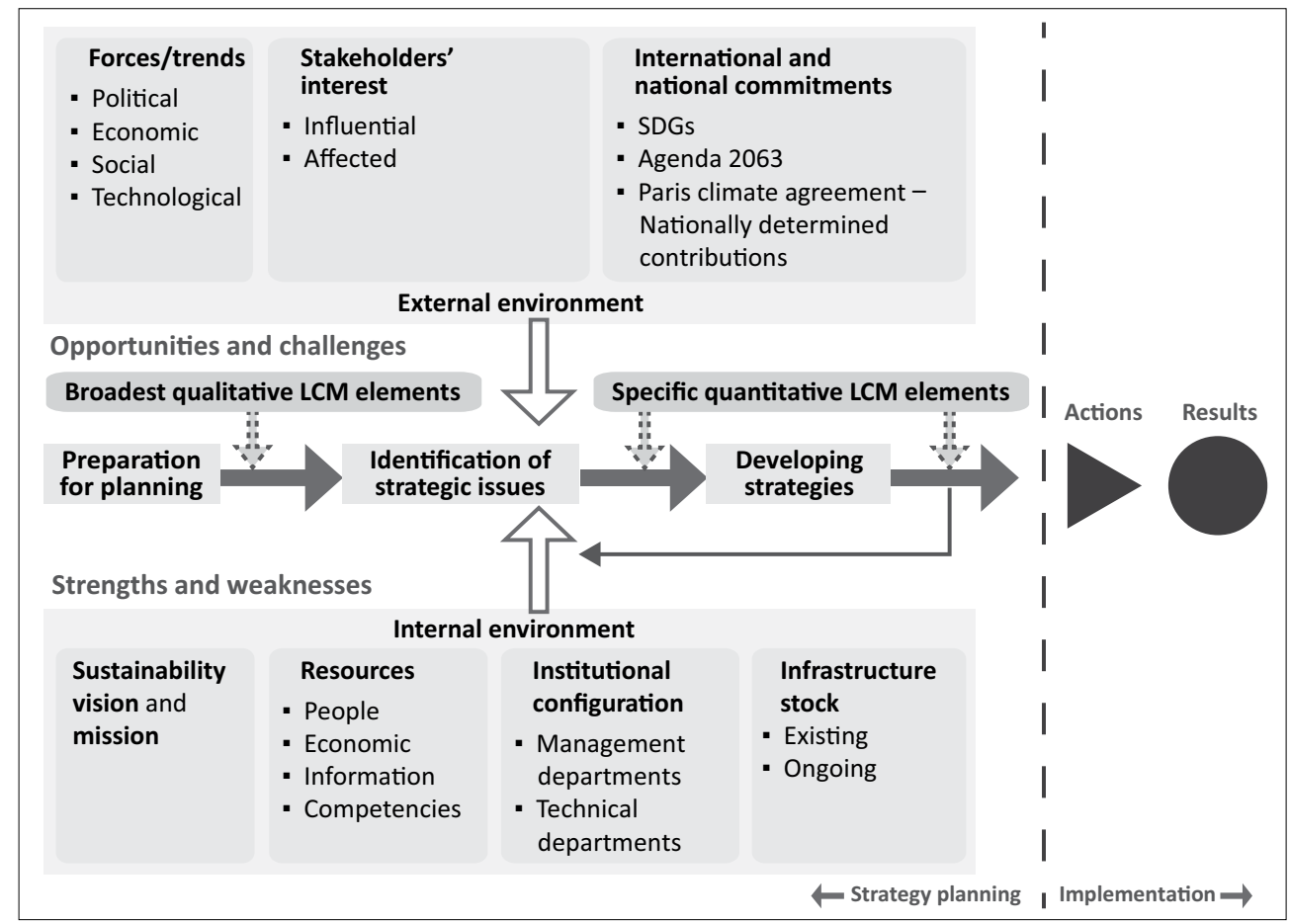

Figure 6.3 Strategic planning process (Source: Diagram adapted from Bryson, 1988:75)

\section{LCM-driven institutional architecture}

In the African national and transnational infrastructure development landscape, there are a many subnational, national and international institutional stakeholders. LCM can be applied to facilitate both technological and institutional reconfiguration in supporting new and effective institutional configurations by realigning influential and affected stakeholders. Recognising the interplay between facts and values, knowledge and opinion, there is a need for moving from conventional evaluation processes of plans to an integrated process that leads to more sustainable outcomes by positively changing the mental models of decision-makers. LCM-driven 
institutional configuration brings order to the knowledge and data surrounding infrastructure systems. It opens the strategy-making and planning process and helps in communicating developed strategies. It facilitates participatory processes not only in the overall process but also in sub-processes such as modelling (PahlWostl \& Hare, 2004). LCM assists in structuring the participation of experts and stakeholders based on where in the life cycle of the infrastructure their impact is more pronounced. LCM analysts can coordinate infrastructure experts and stakeholders to integrate their contributions into the planning and the strategic decision-making process.

One important aspect is having a supra-ministry and inter-sectoral entity that recognises the whole of infrastructure as one system larger than what is normally handled by sectoral ministries, and the need for an independent body of expertise that supports such entity. Box 6.4 presents the National Infrastructure Commission of the UK, which is a good example of such an independent body that supports the government on strategic aspects of infrastructure systems.

\section{Box 6.4: National Infrastructure Commission}

The UK's National Infrastructure Commission (NIC) was established as an executive agency of the Treasury to provide impartial, expert advice and make independent recommendations to the government on infrastructure systems.

The NIC operates independently from the government while advising on all sectors of infrastructure: energy, transport, water and wastewater (drainage and sewerage), waste, flood risk management and digital communications. The NIC considers the potential interactions between its infrastructure recommendations and housing supply.

In carrying out its role, the NIC produces:

- a national infrastructure assessment (NIA) once in every Parliament, setting out the NIC's assessment of long-term infrastructure needs with recommendations to the government; and

- an annual monitoring report, taking stock of the government's progress in areas where it has committed to taking forward the recommendations of the NIC.

The NIC also produces specific studies on pressing infrastructure issues challenges. These are set by the government and take into account the views of the NIC and stakeholders. These studies include recommendations to the government.

The NIC takes a strategic approach, which links long-term priorities with short-term action and considers infrastructure as a system, not as a collection of silos. This approach maintains an international perspective, engages closely with leading-edge expertise and is open to new approaches and ideas.

Reports and analysis from the NIC are of the highest quality and independent of government and all vested interests. The reports make recommendations based on rigorous evidence and develop an evidence base which sets a standard in its quality and breadth.

(Source: NIC, 2017:3) 


\section{Conclusions}

Sustainability of infrastructure systems is closely related to the material aspects of the structures and networks of moving people, goods and services and information. Hence, a better understanding of the use of conventional and new materials is critical. The limitation of the current practice of material choices and utilisation is the focus on traditional criteria of price and limited technical criteria. The type and quantity of materials used should be based on full knowledge of the design, construction, operation and maintenance as well as end-of-life fate of the materials fixed into the structures and networks in permanency. This environmental lens is best complemented by subscribing to the social and economic evaluation of the multiple material-related choices along the life cycle of the infrastructure systems. Good choices and decisions on how these systems are planned and developed have far-reaching impacts on other parts of the economy and society at large. Data and information from natural and social sciences and the humanities need to be purposefully utilised to avoid short-sighted and narrowly-evaluated and approved solutions.

The core principle of sustainable infrastructure planning and development is to assess the benefits, impacts and costs and hence viability of an infrastructure plan on a full life-cycle basis. To support the implementation of this principle in practice, LCM tool for environmental (LCA), economic (LCC), and social impacts (S-LCA) enable engineers, designers, and decision-,makers to better understand the environmental, economic and social impacts of infrastructure and the opportunities that exist to reduce them.

Life-cycle management methodologies help in appropriately identifying and pricing sustainability-related risks and impacts of non-sustainable infrastructure and the broader long-term co-benefits of sustainable infrastructure. This makes a convincing case that sustainable infrastructure not only is better for people and the environment but also makes business sense (Global Infrastructure Basel Foundation, 2017; International Finance Corporation, 2017; International Institute for Sustainable Development, 2017). Another important principle of sustainable infrastructure development is to consider integrated needs in the early stages of planning and delivery for example, integrated approaches linking transportation, mixed-use development and the avoidance of developments in flood plains. The development planning should also encourage biodiversity in city landscapes through the creation of blue-green corridors which integrate water management functions with green infrastructure, sustainable urban drainage systems, etc.

Africa needs infrastructure systems that are planned and developed with sufficient flexibility to accommodate change. The interaction between disciplines and their 
influence within a functioning intellectual ecosystem determines the success of the planning process. The presence of a strategic planning process equipped with proper analytical tools should be matched by a corresponding strategical institutional context. LCM is proposed to coordinate the organisational configuration required to advance sustainable planning, development and management of infrastructure systems in Africa. There is a need for influencing the action space of facts informed by specific quantitative LCM elements and the deliberative space of values by broader qualitative LCM elements. The implementation of the proposed approach is better done through flexible and adaptable processes recognising that planning is more than a structured and linear process.

The proposed approach is meant to contribute to efficiency, increased legitimacy and the general quality of decision making. It is best applied early in the overall strategic planning process of infrastructure systems where it can 'take full advantage of its capacity to strategically influence the strategic direction of PPPs, or the decision-making process itself' (Lobos \& Partidario, 2014: 39). Such early positioning helps to inform the strategic dialogues, define strategic objectives, identify strategic issues and formulate strategic options around the type and size of infrastructure systems. The LCM elements help to broaden the scope of the planning life cycle to account for the full life cycle of the infrastructure system and cover a full range of opportunities and risks. Planning and strategic decision making are currently done in a fragmented way emphasising or overemphasising only part of the bigger reality the planning or the decision making seeks to change. This suboptimal departmentalised approach falls short of capturing the full range of societal benefits of maximising opportunities and minimising risks.

There is a need to look at the whole portfolio of infrastructure systems and find a way to have a low life-cycle impact portfolio by shortlisting alternatives with the best triple bottom line considering external sustainability-oriented economic environments. Whenever possible, the strategic planning needs to account for a shift from large-scale and centralised infrastructure systems to small-scale and diversified capacities. The contribution of LCM to changing the way we currently do strategic decision-making and planning is providing better information and data input to the process and improving the process of planning and decision making. The first entry point of the broadest qualitative LCM elements in the strategic planning process is the earliest stage of where the questions of 'why' and 'what' are asked at the highest level of national decision-making and planning rather than the 'how' questions at the middle or lower subnational level of planning. Institutions that work with this integration need to have the right level of LCM competence for use at each stage of the planning process. 
There is clearly a lag between acquiring scientific knowledge and utilising the new knowledge in practice. A good starting point in dealing with this issue is a gradual trickling of relevant components of the knowledge into the different elements of the planning practice, and in the process, reconfiguring the associated organisational structure to match the new changes. In building the necessary capacity and skillsets, integration of LCM-related subjects in disciplines such as engineering and economics to influence future planners will be important. 


\section{References}

Adibi, N., Darul, M., Pasquest, V., Demaretz, C. \& Traisnel, C. (2017). Life cycle management for regional development in France. Example of building sector. In: S. Massari, G. Sonnemann \& F. Balkau, Life cycle approaches to sustainable regional development. London: Routledge.

African Development Bank. (2013). An integrated approach to infrastructure provision in Africa. Tunis: AfDB.

African Development Bank. (2018). African economic outlook 2018. Côte d'Ivoire: AfDB.

African Union Commission. (2015). Agenda 2063: The Africa we want. Framework document. https://bit.ly/35PLemI [Accessed 20 September 2019].

Ainger, C. \& Fenner, R.A. (2014). Sustainable Infrastructure - Principles into practice. London: ICE Publishing. https://doi. org/10.1680/sipp. 57548

Assefa, G. (2019). Life cycle insights for creating sustainable cities. In: A. Al-Musaed \& A. Almssad (Eds), Sustainable cities: Authenticity, ambition and dream. London: IntechOpen. https://doi.org/10.5772/ intechopen.81633

Barthel, M., Fava, J.A., Harnanan, C.A., Strothmann, P., Khan, S. et al. (2015). Hotspots analysis: Providing the focus for action. In: G. Sonnemann \& M. Margni (Eds), Life cycle management. Dordrecht, Netherlands: Springer. https://doi. org/10.1007/978-94-017-7221-1_12

Bastos, J., Batterman, S. \& Freire F. (2016). Significance of mobility in the lifecycle assessment of buildings. Building Research \& Information 44(4): 376-393. https:// doi.org/10.1080/09613218.2016.1097407

Berger, J.J. (2017a). Stockholm pursues climate Holy Grail: A fossil fuel-free future Part 5: New eco-districts. https://bit. ly/2pweyhs [Accessed 27 February 2018].

Berger, J.J. (2017b). Copenhagen, striving to be carbon-neutral: Part 2, the bold strategy.
https://bit.ly/2MYgpnd [Accessed 27 February 2018].

Bidstrup, M. \& Hansen, A.M. (2014). The paradox of strategic environmental assessment. Environmental Impact Assessment Review 47: 29-35. https://doi. org/10.1016/j.eiar.2014.03.005

Bocajero, J.P. \& Tafur, L.E. (2013). Urban land use transformation driven by an innovative transportation project, Bogotá, Colombia. Case study prepared for the Global Report on Human Settlements 2013. https://bit. ly/31ph8Ty [Accessed 20 September 2019].

Bragança, L., Vieira, S. \& Andrade, A.J.B. (2014). Early stage design decisions: The way to achieve sustainable buildings at lower costs. Scientific World Journal 2014: 1-8. https://doi. org/10.1155/2014/365364

Bryson, J.M. (1988). A strategic planning process for public and non-profit organizations. Long Range Planning 21(1): 73-81. https://doi.org/10.1016/00246301(88)90061-1

Carlson, A. (2011). Life cycle assessment of roads and pavements. Studies made in Europe. VTI report 736A. Linkoping. Sweden: VTI Publications.

Colombo, E., Leon, P., Taisch, M., Cheli, F., Pinzone, M. et al. (2017). Toward smart and integrated infrastructure for Africa - an agenda for digitalisation, decarbonisation and mobility. Rome: The Infrastructure Consortium for Africa (ICA).

Dethier, J.J. (2015). Infrastructure in Africa. In: C. Monga \& J. Yifu Lin (Eds), The Oxford handbook of Africa and economics: Volume 2: Policies and practices. Oxford, UK: Oxford University Press.

Dominguez, D., Truffer, B. \& Gujer, W. (2011). Tackling uncertainties in infrastructure sectors through strategic planning: The contribution of discursive approaches in the urban water sector. Water Policy 13(3), 299-316. https://doi.org/10.2166/ wp.2010.109 
Egler, H-P. \& Frazao, R. (2016). Sustainable infrastructure and finance. Inquiry Working Paper 16/09 June 2016. https://bit. ly/2pxp5J8 [Accessed 20 September 2019].

Egler, H-P. \& Jurik, J. (2017). Sustainable infrastructure: A driver to achieve the sustainable development goals in Africa? Bridges Africa 6(2): 19-22.

Foster, V. \& Briceño-Garmendia, C. (2010). Africa's infrastructure: a time for transformation. Washington, DC: World Bank. https://doi.org/10.1596/ 978-0-8213-8041-3

Geneletti, D. (2005). Multicriteria analysis to compare the impact of alternative road corridors: a case study in northern Italy. Impact Assessment and Project Appraisal 23(2): 135-146. https://doi. org/10.3152/147154605781765661

Global Infrastructure Basel Foundation. (2017). SuRe - the standard for sustainable and resilient infrastructure. Basel: Global Infrastructure Basel. https://bit. ly/2P85s4W [Accessed 15 August 2019].

Goldstein, B., Birkved, M., Quitzau, M. \& Bauschild, M. (2013) Quantification of urban metabolism through coupling with the life cycle assessment framework: Concept development and case study. Environmental Research Letters 8(3): 035024. https://doi.org/10.1088/17489326/8/3/035024

Gu, Z., Vestbro, D.U., Wennersten, R. \& Assefa, G. (2009). A study of Chinese strategies for energy-efficient housing developments from an architect's perspective, combined with Swedish experiences and game theory. Civil engineering and environmental systems 26(4): 323-338. https://doi. org/10.1080/10286600802151853

Guthrie, P. \& Konaris, T. (2012). State of the world report 2012: Sustainable infrastructure. Geneva: International Federation of Consulting Engineers (FIDIC).
Harbi, S., Margni, M., Loerincik, Y. \& Dettling, J. (2015). Life cycle management as a way to operationalize sustainability within organizations. In: G. Sonnemann \& M. Margni (Eds), Life cycle management. Dordrecht, Netherlands: Springer. https:// doi.org/10.1007/978-94-017-7221-1_3

Heinonen, J., Kyro, R. \& Junnila, S. (2011). Dense downtown living more carbon intense due to higher consumption: A case study of Helsinki. Environmental Research Letters 6(3): 034034. https://doi. org/10.1088/1748-9326/6/3/034034

Hertwich, E.G., Gibon, T., Bouman, E.A., Arvesen, A., Suh, S. et al. (2015). Integrated life cycle assessment of electricity-supply scenarios confirms global environmental benefit of low-carbon technologies. Proceedings of the National Academy of Sciences 112(20): 6277-6282. https://doi. org/10.1073/pnas.1312753111

Holmstedt, L., Brandt, N. \& Robèrt, K.H. (2017). Can Stockholm Royal Seaport be part of the puzzle towards global sustainability?-From local to global sustainability using the same set of criteria. Journal of Cleaner Production 140, Part 1: 72-80. https://doi.org/10.1016/j. jclepro.2016.07.019

Inter-American Development Bank. (2018). What is sustainable infrastructure? A framework guide to sustainability across the project cycle. Washington, DC: InterAmerican Development Bank, IDB Invest. https://doi.org/10.18235/0001043

International Finance Corporation. (2017). Financial valuation tool for sustainable development. https://www.fvtool.com [Accessed 15 August 2019].

International Institute for Sustainable Development. (2017). Sustainable asset valuation (SAVi) tool: Helping governments and investors see the value of sustainable infrastructure. https://bit.ly/2TUpEdG [Accessed 20 September 2019]. 
International Resource Panel. (2018). The weight of cities: Resource requirements of future urbanization. A Report by the International Resource Panel. Nairobi, Kenya: UNEP.

Ioppolo, G., Cucurachi, S., Salomone, R., Shi, L. \& Yigitcanlar, T. (2019). Integrating strategic environmental assessment and material flow accounting: A novel approach for moving towards sustainable urban futures. The International Journal of Life Cycle Assessment 24(7): 1269-1284. https://doi.org/10.1007/s11367-0181494-0

Ipsen, K.L., Zimmermann, R.K., Nielsen, P.S. \& Birkved, M. (2018). Environmental assessment of smart city solutions using a coupled urban metabolism - life cycle impact assessment approach. The International Journal of Life Cycle Assessment 24(7): 1239-1253.

Janic, M.( 2003). Multicriteria evaluation of high-speed rail, transrapid Maglev and air passenger transport in Europe. Transportation Planning and Technology 26(6): 491-512.

Jensen, A.A. \& Remmen, A.(Eds). (2006). Background report for a UNEP guide to life cycle management - $A$ bridge to sustainable products. Paris: Division of Technology, Industry and Economics, UNEP.

Karlsson, C., Miliutenko, S., Björklund, A., Mörtberg, U., Olofsson, B. et al. (2017). Life cycle assessment in road infrastructure planning using spatial geological data. The International Journal of Life Cycle Assessment 22(8): 1302-1317. https://doi. org/10.1007/s11367-016-1241-3

Kasioumi, E. (2011). Sustainable urbanism: vision and planning process through an examination of two model neighborhood developments. Berkeley Planning Journal 24(1): 91-114.

Kennedy, C. \& Corfee-Morlot, J. (2013). Past performance and future needs for low carbon climate resilient infrastructure - An investment perspective. Energy Policy 59: 773-783.
Kennedy, C., Stewart, I., Facchini, A. Cersosimo, I., Mele, R. et al. (2015). Energy and material flows of megacities. Proceedings of the National Academy of Sciences 112(19): 5985-5990.

Kwakkel, J.H., Walker, W.E. \& Marchau, V.A.W.J. (2010). Adaptive airport strategic planning. European Journal of Transport and Infrastructure Research 10(3): 249-273.

Lempert, R., Boehlert, B., Groves, D., Neumann, J.E., Strzepek, K.M. et al. (2015). Adaptation to climate change in infrastructure planning. In: R. Cervigni, R. Liden, J.E. Neumann \& K.M. Strzepek (Eds), Enhancing the climate resilience of Africa's infrastructure: The power and water sectors. Washington, DC: World Bank.

Lobos, V. \& Partidario, M. (2014). Theory versus practice in strategic environmental assessment (SEA). Environmental Impact Assessment Review 48: 34-46.

Loiseau, E., Aissani, L., Le Féon, S., Laurent, F., Cerceau, J. et al. (2018). Territorial life cycle assessment (LCA): What exactly is it about? A proposal towards using a common terminology and a research agenda. Journal of Cleaner Production 176: 474-485.

Loiseau, E., Roux, P., Junqua, G., Maurel, P. \& Bellon-Maurel, V. (2013). Adapting the LCA framework to environmental assessment in land planning. The International Journal of Life Cycle Assessment 18(8): 1-16.

Machado, C.G. \& Cavenaghi, V. (2009). Use of life cycle assessment in sustainable manufacturing: review of literature, analysis and trends. Paper presented at the POMS 20th Annual Conference, Orlando, Florida, USA (1-4 May).

Malekpour, S., Brown, R.R. \& de Haan, F.J. (2015). Strategic planning of urban infrastructure for environmental sustainability: understanding the past to intervene for the future. Cities 46: 67-75. 
McKinsey Global Institute. (2016). Bridging global infrastructure gaps. In collaboration with Mckinsey's capital projects and infrastructure practice. McKinsey \& Company.

National Infrastructure Commission. (2017). National Infrastructure Commission framework document. https://bit. ly/2KrnlJm [Accessed 3 April 2019].

Nilsson-Lindén, H., Baumann, H., Rosén, M. \& Diedrich, A. (2014). Organizing life cycle management in practice: Challenges of a multinational manufacturing corporation. The International Journal of Life Cycle Assessment 23(7): 1362-1382.

Noble, B. \& Nwanekezie, K. (2017). Conceptualizing strategic environmental assessment: Principles, approaches and research directions. Environmental Impact Assessment Review 62: 165-173.

Pahl-Wostl, C. \& Hare, M. (2004). Processes of social learning in integrated resources management. Journal of Community \& Applied Social Psychology 14(3): 193-206.

Pegram, G., Seddon-Daines, D., Reddy, S., Sulieman, N. \& Baletta, H. (2017). The political economy of long-lived decisions in Africa: Framework report. https://bit.ly/2BpdH4H [Accessed 14 September 2019].

Petit-Boix, A., Llorach-Massana, P., SanjuanDelmas, D., Sierra-Pérez, J., Vinyes, E. et al. (2017). Application of life cycle thinking towards sustainable cities: A review. Journal of Cleaner Production 166: 939-951.

Programme for Infrastructure Development in Africa. (2011). PIDA: Interconnecting ,integrating, and transforming a continent The regional infrastructure that Africa needs to integrate and grow through 2040. https:// bit.ly/2qlaelk [Accessed 1 February 2019].

Qi, Y., Zhang, Y., Jiang, H., Hou, H. \& Li, J. (2018). Life cycle assessment in urban territories: a case study of Dalian city, China. The International Journal of Life Cycle Assessment 24(7): 1194-1208. https://doi.org/10.1007/s11367-018-1465-5
Rebitzer, G. (2015). Introduction: Life cycle management. In: G. Sonnemann \& M. Margni (Eds), Life cycle management. Dordrecht, Netherlands: Springer.

Saghir, J. (2017). Sustainable infrastructure development in sub-Saharan Africa. Washington, DC: Centre for Strategic and International Studies.

Slagstad, H. \& Brattebø, H. (2014). Life cycle assessment of the water and wastewater system in Trondheim, Norway - A case study: Case study. Urban Water Journal 11(4): 323-334.

Sonnemann, G., Gemechu, E.D., Remmen, A., Frydendal, J. \& Jensen, A.S. (2015). Life cycle management: Implementing sustainability in business practice. In: G. Sonnemann \& M. Margni (Eds), Life cycle management. Dordrecht, Netherlands: Springer.

Sosa, R.O., Espinoza, A.H., Royo, M.G. \& Gálvez, D.M. (2017). Life cycle energy and costs of sprawling and compact neighborhoods. The International Journal of Life Cycle Assessment 22(4): 618-627. https://doi.org/10.1007/s11367-016-1100-2

Sow, M. (2015, 30 December). Foresight Africa 2016. Urbanization in the African context. [Web log post]. https://brook.gs/2BsIcqx [Accessed 15 September 2019].

Truffer, B., Störmer, E., Maurer, M. \& Ruef, A. (2010). Local strategic planning processes and sustainability transitions in infrastructure sectors. Environmental Policy and Governance 20(4): 258-269.

Tudela, A., Akiki, N. \& Cisternas, R. (2006). Comparing the output of cost benefit and multi-criteria analysis: An application to urban transport investments. Transportation Research Part A: Policy and Practice 40(5): 414-423.

Turconi, R., Boldrin, A. \& Astrup, T.F. (2013). Life cycle assessment (LCA) of electricity generation technologies: Overview, comparability and limitations. Renewable and Sustainable Energy Reviews, 28: 555-565. https://doi.org/10.1016/j. rser.2013.08.013 
United Nations Department of Economic and Social Affairs. (2015). The world population prospects: 2015 revision. https://bit. ly/2MtQXqr [Accessed 1 February 2019].

United Nations Economic Commission for Africa. (2017). Africa sustainable development report: Tracking progress on Agenda 2063 and the sustainable development goals. Addis Ababa: UNECA.

United Nations Environment Programme. (2013). City-level decoupling: Urban resource flows and the governance of infrastructure transitions. Report of the Working Group on Cities of the International Resource Panel. Nairobi, Kenya: UNEP.

United Nations Environment Programme. (2015). Green energy choices: The benefits, risks and trade-offs of low-carbon technologies for electricity production. Report of the International Resource Panel. Nairobi, Kenya: UNEP.

United Nations Human Settlements Programme. (2009). Planning sustainable cities: Global report on human settlements. Nairobi, Kenya: UN-Habitat.
United Nations Human Settlements Programme. (2010). The state of African cities 2010: Governance, inequalities and urban land markets. Nairobi, Kenya: UN-Habitat.

United Nations Human Settlements Programme and United Nations Economic Commission for Africa. (2015). Towards an Africa urban agenda. Nairobi, Kenya and Addis Ababa, Ethiopia: UN-Habitat and UNECA.

Wright, H., Dimsdale, T., Healy, C., Orozco, D., Williamson, S. et al. (2018). Sustainable Infrastructure and the multilateral banks: Changing the narrative. E3G Briefing Paper, June. https://bit.ly/2oMEcyu [Accessed 20 September 2019].

Wrisberg, N., Udo de Haes, H.A., Triebswetter, U., Eder, P. \& Clift, R. (2002). Analytical tools for environmental design and management in a systems perspective. Dordrecht, Netherlands: Kluwer Academic Publishers. 